\title{
CHALLENGES OF STUDY, CONSERVATION AND INTERPRETATION OF HISTORICAL AND CULTURAL HERITAGE
}

Collective monograph

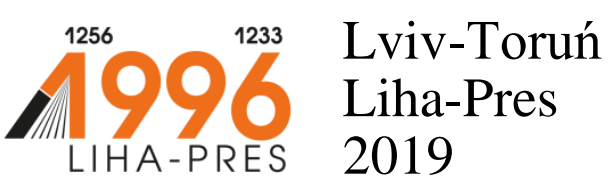




\section{Reviewers:}

Prof. nadzw., dr hab. Stanistaw Kunikowski, Rektor of Cuiavian University in Wloclawek (Republic of Poland);

Prof. dr hab. Joanna Marszalek-Kawa, Uniwersytet Mikołaja Kopernika w Toruniu / Nicolaus Copernicus University (Republic of Poland).

Challenges of study, conservation and interpretation of historical and cultural heritage : collective monograph / V. M. Halyk, H. Z. Hrytsenko, V. I. Ilnytskyi, M. D. Haliv, etc. - Lviv-Toruń : Liha-Pres, 2019. - 100 p.

ISBN 978-966-397-134-6

Liha-Pres is an international publishing house which belongs to the category "C" according to the classification of Research School for Socio-Economic and Natural Sciences of the Environment (SENSE) [isn: 3943, 1705, 1704, 1703, 1702, 1701; prefixMetCode: 978966397]. Official website - www.sense.nl. 


\section{CONTENTS}

THE RESORTS OF CROATIA IN THE LIFE

AND MULTIFACETED ACTIVITIES OF IVAN FRANKO

Halyk V. M.

.1

BELARUSIAN-UKRAINIAN ART RELATIONS

OF THE SECOND HALF OF THE XIXth -

EARLY XXth CENTURY

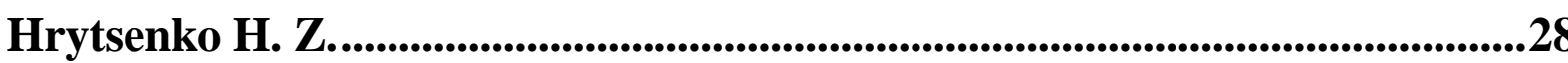

VIOLATIONS OF "SOCIALIST LEGALITY"

AT THE STATEMENT OF THE SOVIET ADMINISTRATION

IN THE CARPATHIAN REGION OF OUN (1945-1954)

Ilnytskyi V. I., Haliv M. D. .48

EVOLUTION OF A HYBRID-INFORMATION WAR

IN THE CONTEXT OF AGGRESSIVE POLICY

OF THE RUSSIAN FEDERATION IN RESPECT TO UKRAINE

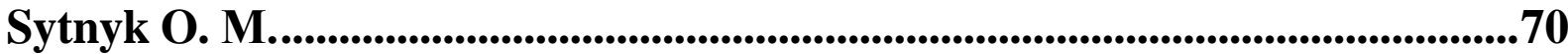





\section{THE RESORTS OF CROATIA IN THE LIFE AND MULTIFACETED ACTIVITIES OF IVAN FRANKO}

\section{Halyk V. M.}

\section{INTRODUCTION}

The outstanding figure of Ivan Franko always was and continues to be the subject of interest not only for Ukrainian, but also foreign scholars. This is evidenced by the fact that many of Ivan Franko's works have been translated into different languages, in many states the name of a prominent Ukrainian scholar is being renewed, museums, memorial tables and, finally, memorials are opened in different cities related to his stay there. In this context, let us look at the Croatian city Lypyk, where on March 10, 2011 a monument to Ivan Franko was opened. This is connected with the fact that the scholar underwent a course of treatment between late March and early April of 1908. While being in Lypyk, I. Franko was actively involved in scientific activities: he studied literature there, was interested in local folklore, wrote poems and reviews.

There is also the second resort town of Croatia, Lovran, which, like the previous one, was the site of Ivan Franko's regular treatment. It was here that the scholar spent almost a month (the beginning of March - the beginning of April 1909), where he underwent a course of treatment in a famous local doctor, Doctor of Medicine at the University of Vienna A. Eder.

Both in Lypyk and Lovran I. Franko, despite the ban of doctors, was engaged in scientific activity. Most of the time he was interested in the works of well-known Slavonic researchers and made translations of their works. It should be noted that the doctors allowed him to be engaged in easier scientific activities. That was the translation: scholar has translated a number of works of culture.

Looking at the creativity of the scholar of this time, we see that he was worried about his disease, but tirelessly fought with it, sometimes even in strange ways. In fact, from that moment on in the life of Ivan Franko, a kind of the beginning became the end, from 1908 to 1916 (almost 8 years) he was attacked by constant mental disorders, nervous 
breakdowns, which, of course, influenced scientific activity. Although the disease receded from time to time, and then escalated again, that period of life was for the scholar not only years of severe pain and suffering, but also fruitful creative work.

\section{Ivan Franko and Lypyk}

Croatian city Lypyk primarily known as a health spa resort on a European area. Here I. Franko was on the recovery from the second half of March to the first half of April 1908. The reasons for this trip are learned from the memories of M. Mochulskyi, who writes that before Christmas in 1908 he visited I. Franko with the purpose of borrowing several books for work. However, at that time he did not notice that the scholar had health problems, but when he visited him a second time, at the end of February 1908, he saw him lying "in his bedroom on a bed", undressed and easily covered with a blanket. When the visitor entered the room, Franko jumped out of the bed and sat down on it. During the conversation he complained of "frequent migraine attacks", which rarely lasted for several days, "a left hand aches very much that he cannot sleep because of it". I. Franko mentions about his illness in the article "History of my illness", where he says that at this time he felt completely exhausted, he suffered headache and ringing in his ears twice a week, because of which he was forced to see a doctor ${ }^{2}$. F. Vovk was reported on his poor state of health on February 20, 1908: “... I am broken by a serious illness, now I cannot think..."”3.

Ivan Franko was treated by Lev Kossak. He had been taking care of his health for many years, but stressed that his patient was very disrespectful and disobedient ${ }^{4}$. During the treatment, I. Franko had to

${ }^{1}$ Мочульський М. 3 останніх десятиліть життя Івана Франка (1896-1916): Гнатюк М. упор. Спогади про Івана Франка. Львів: Каменяр, 1997. С. 439-440.

2 Франко I. Історія моєї хвороби: Інституту літератури ім. Т. Г. Шевченка НАН України (далі - І. Л.). Ф. 3. Спр. 185.; Франко І. Історія моєї хвороби / Публікація Ярослави Мельник: Парадигма / Інститут українознавства НАН України. Львів: Критика, 1998. С. 179.; Мельник Я. I остання часть дороги... Іван Франко: 1908-1916. Дрогобич, 2006. С. 385.

${ }^{3}$ Франко І. Лист до Ф. К. Вовка від 20 лютого 1908 р. із Львова: Франко І. Зібрання творів у 50-ти т. (далі - Франко І. Зібр. тв.). К., 1986. Т. 50. С. 351.

${ }^{4}$ Мочульський М. Іван Франко: Студї̈ та спогади. Львів, 1938. С. 149. 
follow a diet, he was forbidden to read and write ${ }^{5}$. In a letter to M. Hrushevskyi, the scholar writes that his "health... has deteriorated a bit. There is something behind the cerebellum, the center of pain in the size of a silver guilder and not giving back, as if in a hold. I am competing and holding on and doing something, not counting the pressure of my head"6.

But at this time, when I. Franko decided to use the services of a physician, the treatment was ineffective, so L. Kossak advised the scholar to refrain from work, but not to be bored, he allowed to do translations ${ }^{7}$ and, finally, "to go to Lypyk to be treated with iodine water". In the second half of March 1908, I. Franko began to travel ${ }^{8}$. Before leaving visited the council meeting of the Scientific Society of Shevchenko, where he edited the second volume of "Galician-Ruthenian folk prypovidky"9. According to M. Hrushevskyi, on March 21, 1908, I. Franko went on a journey to Croatian town-resort Lypyk in "full consciousness, with busy plans and then announce about plans" ${ }^{10}$. When he went there, he arranged with V. Hnatyuk that he would translate the shameful materials he had collected over several years and took with him over a hundred of stories ${ }^{11}$.

I. Franko arrived in Lypyk on March 24, 1908. In his letter to M. Hrushevskyi, he wrote that he had safely stopped in and started a medical examination. In the context, we would like to emphasize that the letter of Ivan Franko to M. Hrushevskyi, which was submitted in volume 50 of Ivan Franko's works under number 342, had an error in the date of the letter, it was dated June 1908, from Lypyk, and the note of "The Dilo" newspaper No. 87 dated April 18, 1908, it is known that the scholar had already returned from Lypyk by this time, namely,

${ }^{5}$ Франко І. Лист до М. С. Грушевського від [першої половини квітня 1908 р. із Липика]: Франко І. Зібр. тв. Т. 50. С. 355.

6 Там само.

7 Гнатюк В. Франко в Липику: Іван Франко у спогадах сучасників / Упоряд. передмова та примітки О. І. Дея. Львів, 1972. Кн. II. С. 247.

${ }^{8}$ Мочульський М. 3 останніх десятиліть життя Івана Франка (1896-1916)... C. 440 .

9 Там само.

${ }^{10}$ Грушевський М. Недуга д-ра Івана Франка: Літературно-науковий вістник. Львів - Київ, 1908. Т. XLII. Кн. V. За май. С. 405.

${ }^{11}$ Гнатюк В. Франко в Липику... С. 247. 
April 16, 1908, after which he was undergoing treatment at Svitalskyi sanatorium in Lviv. At the time of arrival, the weather in the city was bad, but the medical staff was good for I. Franko and encouraged him to recover. Further, he asks M. Hrushevskyi: "Please send me those initial cards of the theological article that I have left at yours', and I will shortly send you its completion, and maybe another one, because there is nothing else to do here. I do not think of the original creativity, and it is not time before the spring opens. Today I started the fonts, but I still can't feel the result, my arm hurts awfully"12. At the end of the letter, he noted that he had the intention to get acquainted with the local "scientific circle",

Before the end of March, I. Franko sends a postcard with "obrazok" (a picture) of landscapes of Lypyk to his daughter. Here he writes: "Dear Gandzya (Anna). Here are the pictures from Lypyk if someone does not steal on the way. You do not think that here the scenery is so beautiful as in the pictures. Trees, like those on pictures, are still bare, it is cold outside as at home, and there is nobody and nothing interesting in the streets. The tiny houses and the beautiful villas between them are now empty. That's when it is warm, there will be a lot of parishioners, it will not be so, but I hope to be ready and leave by the time" 14 .

March 31, 1908 I. Franko writes to his doctor L. Kossak the response to the received letter on that day, in which, he questioned him how his treatment went on ${ }^{15}$. Sincerely thanking him for the correspondence, he notes that he was very comforted by it, and describes the treatment: "I drink iodine water early and in the afternoon a quarterliter [in] 3 glasses, 3 or 4 glasses at a time, of course, with stops. I started doing massages on Sunday" ". As we can see, Ivan Franko was

12 Франко І. Лист до М. С. Грушевського від 24 березня 1908 р. із Липика: Франко І. Зібр. тв. Т. 50. С. 351-352.

13 Там само. С. 352.

14 Франко-Ключко А. Рукопси Івана Франка в Канаді: Для Тебе Тату / Упоряд, автор вступної статті й копентарів М. Шалата. К., 2010. С. 245.; Франко-Ключко А. Рукописи Івана Франка в Канаді: (Лист із Липика, Югославія, та інше). Вінніпег, 1957. URL: http://library.kr.ua/elib/franko/franko-rukopis.html.

${ }^{15}$ Коссак Л. Лист до І. Франка від 31 березня 1908 р. із Львова. І. Л. Ф. 3. Спр. 50. С. 352-353.

${ }^{16}$ Франко І. Лист до Льва Коссака від 31 березня 1908 р. із Липика: Франко I. Зібр. тв. Т. 50. С. 352. 
massaged by a professional massage therapist, who was a very pleasant man, a Croat by nationality, serving in Galicia, where he was interested in Galician affairs. I. Franko spoke with him in German. As for his state of health, he states: "... the hand does not hurt no longer. I put it twice in hot iodine water right here at the source, and it does very well for me. In the bath the water is a little too cold for me, $30^{\circ}$ in the pouring wave, but quickly gets cold. I asked the doctor to give me warmer up to $35^{\circ}$, and it seems to me that it will bring my recovery faster". I. Franko lived here alone in a small room, the owner of which was Pavlyachek ${ }^{17}$.

The same day, answering to his wife's letter, I. Franko tells in detail about his treatment, the story is relevant to the story for L. Kossak), where he lives, and asks if his daughter Anna received a postcard with a large view of Lypyk"18. The husband further asks his wife to send him "a leaflet with an extract from "The life of Vasil the New" from Keltuyala". In addition, he notes that "every night" he talks to "Celina she is, certainly, in Drohobych. We speak in a sleep, via spirit's mail. This is where this mail brings me interesting news, including from Domanitskyi. Because of her, I was at Shevchenko organization's meeting tonight in St. Petersburg" "19. This shows that the state of the scholar worsened, he was pursued by chimeras.

Olga Franko fulfilled the request of her husband, which we learn from a letter to her on April 6, 1908 from Lypyk: "Dear mother! Your beloved letter I added to the letter of Keltuyala, I got it at night, and I answer now, because I am very depressed by my illness and have no hope in my life any further" 20 . From the letter we see that the scholar does not know how much longer he will be treated in Lypyk. He predicted it could be a week or even two. Apparently, the wife reported that the family lacked money for housing, as I. Franko tells her to contact V. Hnatyuk, or to send his son Andrew to him and asked him to write for I. Franko "A cheque for a sum of money" his wife would needed to live on until Franko's return from Lypyk ${ }^{21}$.

17 Там само.

18 Франко I. Лист до О. Ф. Франко від 31 березня 1908 р. із Липика: Франко I. Зібр. тв. Т. 50. С. 353.

19 Там само.

${ }^{20}$ Франко І. Лист до О. Ф. Франко від 6 квітня 1908 р. із Липика: Франко I. 3ібр. тв. Т. 50. С. 353-354.

${ }^{21}$ Там само. С. 354. 


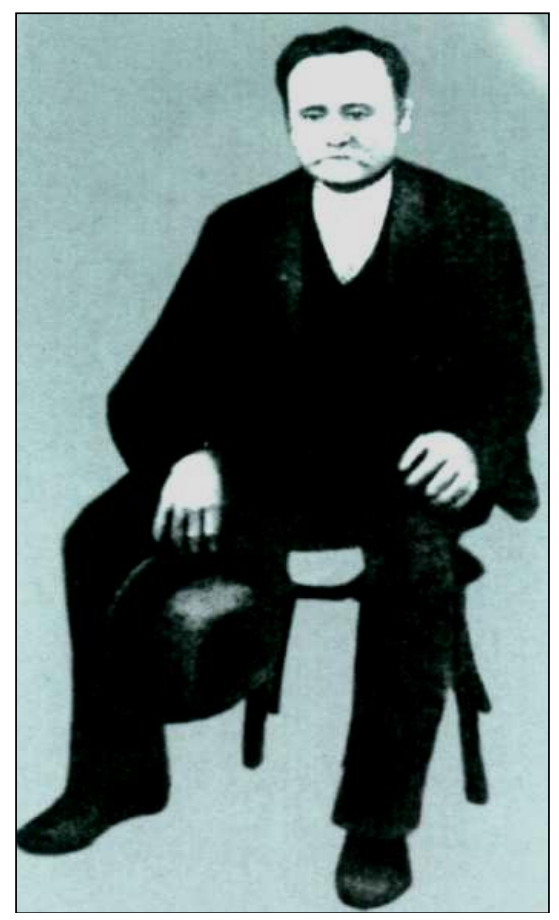

\section{Ivan Franko during the therapy treatment. The end of March - the beginning of April 1908}

The next day, Ivan Franko again wrote to his wife: "I was in such disarray yesterday and oppression that have forgotten to put into thy letter this list to Mr. Keltuyala in St. Petersburg". As for his health, he says he had a visit to a doctor Braithweiser, who said it would take three or four more weeks for treatment ${ }^{22}$. Already on April 8, this year, his wife wrote off to her husband who had a hope for an early meeting, that she would take money in the Credit Union, and about his health, she said: "Why are you so worried about your weakness? Remember, in Zavadiv 10 years ago, you were the one who was oppressed and hoped for a speedy death. And thanks God, we lived in peace. But everything is in the hands of God... "23.

However, the worries of Ivan Franko were not without grounds. The treatment in Lypyk did not go for good. His daughter writes in her memoirs that his hope of soon recovery has not been fulfilled. Soon the family receives a telegram from the resort, which stated that Franko is in a bad state and needs to be taken home, as did his son Taras. But despite

${ }^{22}$ Там само.

${ }^{23}$ Франко О. Лист до І. Франка від 8 квітня [1908 р.] зі Львова. І. Л. Ф. 3. Спр. 1636. С. 37-38. 
the fact that the scholar was seriously ill and suffered from the relentless paralysis of his hands, he still continued to write, and nothing but poems. Unfortunately, they had an immoral content, so Taras burned them in Lypyk ${ }^{24}$. The translations of stories, which Ivan Franko took from V. Gnatyuk were burned as well ${ }^{25}$. About immoral content of the poems also mentions in his memoirs E. Chykalenko who writes that the scholar sent him to "The "Rada" two poems about academic Veselovskyi, and they were so immoral that even could not be read aloud, they were too "pornographic" for publishing ${ }^{26}$.

Here, perhaps, the scholar's worldview was influenced by hallucinations, which were reflected in the story "Big Noise", which contained a hallucinatory-romantic elements and shameful words $^{27}$. Taking that into account, the publishing house of "LiteraryScientific Herald" in the publication of the work in 1908 made some adjustments $^{28}$.

However, not all of Ivan Franko's works from Lypyk were extremely bad. M. Mochulskyi recalls that they, together with V. Hnatyuk, went to visit the Franko's family and see if any manuscripts had been brought from Croatia. They were told that all the manuscripts had been burned by his son Taras in Lypyk at the request of I. Franko himself. However, looking through one of the books the scholar had with him, he found three "poetry books" on a sheet of white paper. These were: "Though you will forget me ...", "You call me again, my goddess", "Honor to the creator of creatures" (excerpt), and they could be "called the poet's swan song", Having read poetry aloud, M. Mochulskyi and V. Hnatyuk were very fond of them, especially the first one. Even Franko's wife, when she heard the poetry "Although you will forget about me ..." rejoiced, thinking that her husband had written it for her.

${ }^{24}$ Франко-Ключко А. Рукопси Івана Франка в Канаді... С. 245.

${ }^{25}$ Гнатюк В. Франко в Липику... С. 247.

26 Чикаленко Є. Іван Франко: (Уривок із споминів): Наша громада. 1926. Кн. 5-6. С. 17.

${ }^{27}$ Мочульський М. Іван Франко: Студї та спогади. Львів, 1938. С. 129.

${ }^{28}$ Франко I. Зібр. тв. Т. 22. С. 507-508.

29 Мочульський М. 3 останніх десятиліть життя Івана Франка (18961916)... C. 387. 
However, according to M. Mochulskyi, it was not devoted to Franko's wife, since when he reprinted itr in the collection "Ancient and new", he gave it the title "To unnamed Mary" 30 . The poetry written by Ivan Franko in Lypyk, were printed on the pages of "The LiteraryScientific Herald" and "The Memoirs of the Shevchenko Scientific Society", that was evidenced by Myhailo Grushevskyi ${ }^{31}$.

About hallucinations and visions in Lypyk I. Franko told the correspondents. These stories were impressive. In particular, in a letter to F. Vovk dated April 2, 1908, he complained that nightmares disturbed him at night and did not allow him to sleep at all, or flooded him in a hot dream and very tormented his soul: "Even now, my health is not very wise, but, most of all, my soul and thinking are so sluggish, exhausted, dull and grieving that I can't even think of any, at least a little original work. It's just that the pen falls out of my hands, and when I write in connection a few words, I will probably miss a few letters and the nonsense comes out ${ }^{\text {"32 }}$.

Taking care of this state, Franko tried to drive away from endless visions, but, as he says, some invincible force overtook them again and again. Unable to explain it, he sought help from others. So, saying to W. Domanytskyi how one night in a dream he had read the letter, addressed to Scientific Society of Taras H. Shevchenko in Lviv, and even some article by an unknown author, which was directed against him personally and asked to inform the recipient, if this may be true ${ }^{33}$. I. Franko insisted on the answer, as he needed it badly to make sure that he was dealing with hallucinations or with the first manifestations of madness ${ }^{34}$. In this connection, I. Franko begins to believe that he receives the gift of communicating through the mail of spirits ${ }^{35}$.

${ }^{30}$ Tам само.

${ }^{31}$ Грушевський М. Недуга д-ра Івана Франка... С. 405.

32 Франко І. Лист до Ф. К. Вовка від 2 квітня 1908 р. з Липика / Публікація Ярослави Мельник: Парадигма. Зб. наук. праць / Ін-т українознавства ім. І. Крип'якевича НАН України. Львів, 1998. С. 189-190.

${ }^{33}$ Франко І. Лист до В. Доманицького від 27 березня 1908 р. з Липика / Публікація Ярослави Мельник: Парадигма. Зб. наук. праць / Ін-т українознавства ім. І. Крип’якевича НАН України. Львів, 1998. С. 183-185.

${ }^{34}$ Там само. С. 185.

35 Франко І. Лист до О. Ф. Франко від 31 березня 1908 р. із Липика: Франко І. 3ібр. тв. Т. 50. С. 353. 
On April 2, 1908, I. Franko wrote again to Domanitskyi, where he reports: "As for my life in Lypyk, I do not think that I will be here by the end of April, as I will only finish the course of treatment given by my doctor, I will leave home from now on, I will not do there anything new, especially in fiction, because I do not feel no strength, but I will continue to lead my own parables and the publication of apocryphal and narrative literature, and the relevant scientific works on the topic of interest for me... Life in Lypyk is very cheap and quite good, cheap wine of own production, light and very good, liter costs one krona and is drunk well and does not harm anything. Time is not special here; the last days of March and the first of April are quite cold and uninviting and no better than ours in Eastern Galicia"36.

In the article "History of my illness" I. Franko tells about one of such conversations, which ended for him tragically. A fantastic accident occurred in Lypyk when he lay in a fever the night 7 to 8 April 1908. As he said he was awaken by spirits and was commanded to exit the chambers, and then drove the road that led to the field and threatened with death and forced to get undressed. When he was only in his shirt, the spirits commanded him to get off the road, go over the ditch, climb over the raft, and then drive on to the meadows. There he was driven from puddle to puddle, forbidden to return to Lypyk. Finally, Franko was tried and sentenced to hell, and before that he had to be imprisoned on some mountain for 18,000 years. Some time after, the souls of the late I. Naumovich and I. Galushevich appeared before him, made reproaches to him, and finally, left in the midst of the swamp for the lime of this road. Here, in fear, Franko stayed until 10 o'clock in the morning, and was found by a gendarme Tarnavskyi, who lived near him. The disappearance of I. Franko from Pavlyachko's chamber made a fright, and he was sought until the morning ${ }^{37}$. Some scenes from

${ }^{36}$ Франко І. Лист до В. Доманицького від 2 квітня 1908 р. з Липика / Публікація Ярослави Мельник: Парадигма. Зб. наук. праць / Ін-т українознавства ім. І. Крип’якевича НАН України. Львів: Класика, 1998. С. 187.

37 Франко I. Історія моєї хвороби / Публікація Ярослави Мельник: Парадигма... С. 180-181. 
"History of my illness" Franko placed in the story "Cross paths"38 and the poem "Funeral" 39 .

I. Franko also told V. Hnatyuk about that incident in a letter dated April 10, 1908. We also learn from the letter that during this adventure he lost his clothes, a purse with money (about 185 crowns) and a watch. However, soon the clothes was found, and the rest - no. Therefore, he asked V. Hnatyuk to send him 200 crowns, since he had to pay for the services provided. Concluding the letter, I. Franko said: "Tell my wife of my adventure and reassure her whenever possible. Apart from the material loss, thank God, it did not seem to bring harm to my health"40.

The fact that Ivan Franko was in Lypyk in a serious condition was also reported by "The Dilo" newspaper on April 11, 1908. In particular, the Novelties section stated that Dr. Ivan Franko, who had been ill for a long time, left three weeks ago on the advice of a doctor in a Kupel area in Lypyk Slavonia. Two days ago, the patient's condition worsened so much that he was transported to the neighboring area of Pankrat, to the hospital. Yesterday the son Taras went to the sick..." ${ }^{41}$. A week later, April 18, "The Dilo" informed that health of I. Franko did not improve, he came to the city with his son Taras on 16 April and is being treated in a sanatorium of Dr. S. Svyontovskyi ${ }^{42}$.

The first days of hospital stay, no visitors were admitted to I. Franko. Often, medical staff complained about the patient because he did not want to follow the advice of doctors, ran away from the sanatorium ${ }^{43}$. On April 28, "The Dilo" newspaper appealed to the residents of Lviv and its suburbs with the request of the sanatorium doctors not to visit the patient, since he only needed peace ${ }^{44}$. Ivan Franko stayed at the hospital for three months, but his condition did

${ }^{38}$ Франко I. Перехресні стежки: Франко I. Захар Беркут. Перехресні стежки. Оповідання. К., 2006. С. 177-462.

39 Франко І. Епілог: Франко І. Похорон. Поема. Львів, 2008. С. 52-54.; Франко I. Епілог: Франко I. Похорон: Франко I. Зібр. тв. Т. 5. С. 87-89.

${ }^{40}$ Франко І. Лист до В. Гнатюка від 10 квітня 1908 р. з Липика / Публікація Ярослави Мельник: Парадигма. 3б. наук. праць / Ін-т українознавства ім. І. Крип'якевича НАН України. Львів, 1998. С. 191-192.

${ }^{41}$ Новинки: Дїло. Ч. 81.11 цьвітня. Львів, 1908. С. 3.

${ }^{42}$ Новинки: Дїло. Ч. 87. 18 цьвітня. Львів, 1908. С. 3.

${ }^{43}$ Мочульський М. Іван Франко: Студї та спогади... С. 156.

${ }^{44}$ Новинки: Дїло. Ч. 97. 28 цьвітня. Львів, 1908. С. 4. 
not improve. Anna, his daughter, mentions: "Daddy was lying on the bed, or sitting, wrapped in a blanket, in a comfortable chair. His disease altered face, it was pale, his eyes were even sadder. He complained of pain in his hands and asked me to straighten them. When my efforts failed, he complained that spirits did $\mathrm{it}^{45}$. Due to the poor condition of the scholar, he was helped by friends, scientific institutions and the press. In particular, "The Dilo" appeared under the heading "For the sick writer". It declared the amount of donations collected for the treatment. According to "Novelties", the newspaper of April 21 and May 2, 1908 were among the first benefactors were: acquaintances, friends and others ${ }^{46}$.

M. Hrushevskyi also reported about the grave condition of I. Franko on the pages of "The Literary-Scientific Herald" of April 30, 1908, noting that "On the second day after his arrival to Lviv he was placed in a lunatic asylum. After a few days there were symptoms of improvement, reassurances, which gave the doctors the reason to expect the recovery; but these useful acts then ceased. The consciousness is incomplete: the ill turns to the mischievous ideas that have captured him. Therapeutic treatment has begun, in just a few weeks it will be possible to know if it succeeds" $"$. Due to the fact that the funds for the maintenance and treatment of Franko began at the sanatorium, on the initiative of M. Hrushevskyi, the department of the Scientific Society of T. H. Shevchenko "succeeded with private letters to the people known that Dr. Franko was brought to the city, and for this purpose from Galicia it was got above 2,000 crowns, while from russian Ukraine above 1000 rubles". Further M. Hrushevskyi emphasizes that further collected "money for this purpose in Ga;icia should be sent to the Regional Credit Union in Lviv (booklet 5000) and in Russia to the Lit.Scientific Herald". Concluding his post, he optimistically emphasizes: "We hope that a strong organism, in the good circumstances of the sanatorium, will overcome the illness, and the spiritual strength of our highly respected employee will return!"48.

45 Франко-Ключко А. Іван Франко і його родина... С. 142.

46 Новинки: Дїло. Ч. 90. 21 цьвітня. Львів, 1908. С. 4.; Новинки: Дїло. Ч. 101. 2 мая. Львів, 1908. С. 4.; Новинки: Дїло. Ч. 143. 20 червня. Львів, 1908. С. 4.

${ }^{47}$ Грушевський М. Недуга д-ра Івана Франка... С. 405.

${ }^{48}$ Там само. С. 406. 
The hopes of M. Hrushevskyi come true: in the late summer, I. Franko felt better a little. This news was told by "The Dilo" newspaper on August 1, 1908, in a small note: "We can now share the good news with our entire community. The pride of our people, a prominent worker in our spiritual life, Dr. Ivan Franko, feels better that he has already left the sanatorium and remains at home. Honorable convalescent has already taken to his literary work" ${ }^{\prime 9}$. The newspaper further reports that Ivan Franko is still unable to write his own works, and this work is done for him by his sons. Wishing the scholar fruitful work, the journal emphasized that "In this case, however, our citizenship on both sides of the border should not forget for a moment that the longing of the [renowned] writer and his further health depends mainly on him not being imprisoned for continuous, depleting labor on his daily bread. The news of Dr. Franko's ailment will be the contagion of the best dementi low remarks about his personality, made about ailments by low souls in the Moscow press and the reptilian press" ${ }^{30}$.

About the improvement of Franko's health also reported Kiev magazine "The Rada" in the fall. It contained a publication titled "To the state of Dr. Ivan Franko's Health", which was caused by the readers' letters with questions about I. Franko's well-being and health ${ }^{51}$. The note said that at the end of August, the scholar was able to leave with his family to Ivan Kuziv in the village of Didyovo in Turchansk county. A week later, his wife with his younger son and daughter returned to Lviv, and he with his two older sons stayed for another week. His acquaintances advised him to take care of his health, to go, for example, "to Lindenwiese on Schleszk", to be treated by "electrification", etc., but he "did not find a willingness to go anywhere", since after his trip to a priest I. Kuziv his state of health improved somewhat and he considered himself ".. healthy, only he cannot own his hands, but nobody will help him with this" ${ }^{, 52}$. Also, the newspaper reported that I. Franko "from time to time goes out to the city, visits friends, can do easier work; now he ends up with prypovidky, continues his "Apocrypha" slowly, is going to

${ }^{49}$ Новинки: Дїло. Ч. 171. 1 серпня. Львів,1908. С. 4.

50 Там само.

51 До стану здоровля д-ра Ів. Франка: Рада. Газета політична, економічна і літературна. К., 1908. № 218. 24 сентября (7 листопада). С. 1.

52 Там само. С. 2. 
dictate comments on carols, etc". However, according to "The Rada", paralysis of hands prevented him from doing all this on his own, so he had to dictate to his sons, and they already wrote for him ${ }^{53}$.

Concerning the collection of money for treatment, controversial articles of contemporaries began to appear in the press, which with their content proved to the people that Ivan Franko deserved for his whole work a gift, not a donation. Specifically, on October 24 the newspaper "the Rada" on its pages put a note entitled "Collections for the ill writer", whose author was Lozynskyi. It mainly focuses on I. Franko in the context of the legend of Alfonso Dode about a man with a "golden brain". Further, the author fervently opposes the notion of "Collections for the Ill Writer", asking why it cannot be "A National Gift for Ivan Franko". Concerning this point M. Lozynskyi notes: "The lowest state employee would have deserved for himself the peace and security for the last days of his life! What about him? Deserved "Collections for the Ill Writer...". For thirty year service to 30 million Ukrainian people! A son of Adam Mickiewicz, a gray-haired grandfather, was given a life time pension by the Galician Seim. An ordinary man, only Adam Mickiewicz's son. However, we do not have Seim. But there is a 30 million people, but there are people's institutions, but there are people who constitute them of the tens and hundreds of thousands. And he was the glory of the people, the support of his literary and scientific institutions, and those people who number them in the tens and hundreds of thousands were his acquaintances, friends and comrades, his students and admirers" $" 54$.

Concluding his post, M. Lozynskyi indignantly emphasized: "Alms - and - Ivan Franko! We understand that these words cannot stand by themselves. But we were not able to cross out the word "alms" and put in the place something else that was worthy of the name of Ivan Franko - we crossed out the name of Ivan Franko and put in this place: "the ill writer". But we must understand that it is not worthy of us. It is a good idea to strike out as soon as possible "collections for the ill writer"

53 Там само.

54 Лозинський М. Складки на хорого письменника: Рада. Газета політична, економічна і літературна. К., 1908. № 243. 24 октября (5 грудня). С. 1. 
and to put something that is worthy of the name of Ivan Franko and worthy of us ${ }^{55}$.

In the context, we note that in the second half of the first decade of the twentieth century I. Franko was in a severe financial crisis and did not even have the means to keep his house and bring his sons to university. Therefore, in the fall of 1906 he intended to sell his NSS (National Society of Shevchenko) library, as he said in his letter to his head: “... I do not see an opportunity to keep a house further and pay taxes and bank interests... I must eliminate my interest with the house at the same time the library. I collected it during the difficult times of my life and rejoiced in the hope of giving it the whole to NSS. Now I see that beggars cannot make such gifts, and I turn to you to the head of the Society with the question: Would you consider it possible the Society will buy this library? As for the price, I do not put any amount, let the Society delegate somebody who knows, and let them evaluate how they know"56. But Franko never realized his plan.

Two years later, in the fall of 1908, V. Hnatyuk, seeing that I. Franko needed considerable funds for treatment, reminded him of the intention, but received a negative answer. The scholar said that he was not going to die, and therefore did not see the need to sell the library, because he wants to work more and because of this he will need books ${ }^{57}$.

At this time, Franko did not stop fighting with his illness. To make his hands work, he tried different real and sometimes illusory methods, and with perseverance and imagination tried all the means. One of them is learned from the memoirs of D. Doroshenko, who wrote that Ivan Franko also carried with him a jar filled with a solution of creosote to divert the pursuit of ghosts whom he considered to be the main culprits of his illness, sprinkling around himself. He seemed that the ghosts varnished in that way. Creosote cankered his fingers, his skin cracked and licked, bundles of hands were a kind of red scary wound"58.

55 Там само. С. 1-2.

56 Франко І. Лист до М. С. Грушевського від 27 жовтня 1906 р.: Франко I. Зібр. тв. Т. 50. С. 299.

${ }^{57}$ Мельник Я. Бібліотека Івана Франка: Бібліотека Івана Франка. Науковий опис. У чотирьох томах. К., 2010. Т. І. С. 28.

58 Дорошенко Д. Останній побут Івана Франка у Київі (Сторінка із спогадів): Літературно-науковий вістник. Львів, 1926. Т. ХC. Кн. VII - VIII. За Липень Серпень. С. 282. 


\section{Ivan Franko and Lovran}

In the spring of 1909 I. Franko continued the treatment - another Croatian resort Lovran in a famous local doctor, Doctor of Medicine, University of Vienna A. Eder (born in Vienna in 1859 - died in Bristol in 1916), who headed the sanatorium here from 1909 to $1916^{59}$. But before that, on February 8 , 1909, the Chronicle "The State of Health of Dr. Ivan Franko" appeared in "the Dilo" newspaper which stated: "In the health of Dr. I. Franko was a change that there is the need to leave Lviv. On February 1, the patient with his son Andrew left and stopped just in Fiumum, where the weather is pretty good now. He intends to stay there for a month, and if the weather changes, then he plans to go to Italy"60.

However, Franko's plans were somewhat different from what we can learn from his letter to V. Domanitskyi. As early as April 1, 1908, he wrote: "I would like to spend a few more weeks on the shore of the Adriatic sea, in Abaciya or in Lovran, where our writer Nadiya Kybalchych, married Kozlovska, lives with her ill husband, a wonderful person, whom I wanted to get to acquainted closer" ${ }^{\prime \prime 1}$. The intentions of I. Franko came to fruition almost a year later, as we learned from the newspaper "the Galichanin" of February 11, 1909: "Dr. Ivan Franko is presently in Lovran [and] over the Adriatic sea. His health is improving" $" 62$.This information was confirmed by the subsequent issue of "the Dilo" newspaper, in which on February 20, 1909, it was reported that "Dr. Ivan Franko is now, as we are told, over the Adriatic Sea in Lovran, the Central Hotel. The ill writer, whose health is improving every day, is helped by his son Andrew" $"$.

${ }^{59}$ Simper S. A century of health and sea bathing tourism in Lovran: one hundred zears from issuing the first therapz regulations (1909-2009): Acta med-hist Adriat. Lovran, 2009. № 7(1). S. 145-148.

${ }^{60}$ Новинки. Стан здоровля д-ра Івана Франка: Дїло. Ч. 28. 8 лютого. Львів, 1909. C. 3.

61 Франко І. Лист до В. Доманицького від 2 квітня 1908 р. $з$ Липика... C. $187-188$.

${ }^{62}$ Всячина: Галичанинъ. Львовъ, 1909. 11(24) февраля. С. 3.

${ }^{63}$ Новинки. Д-р Іван Франко ...: Дїло. Ч. 37. 20 лютого. Львів, 1909. С. 4. 


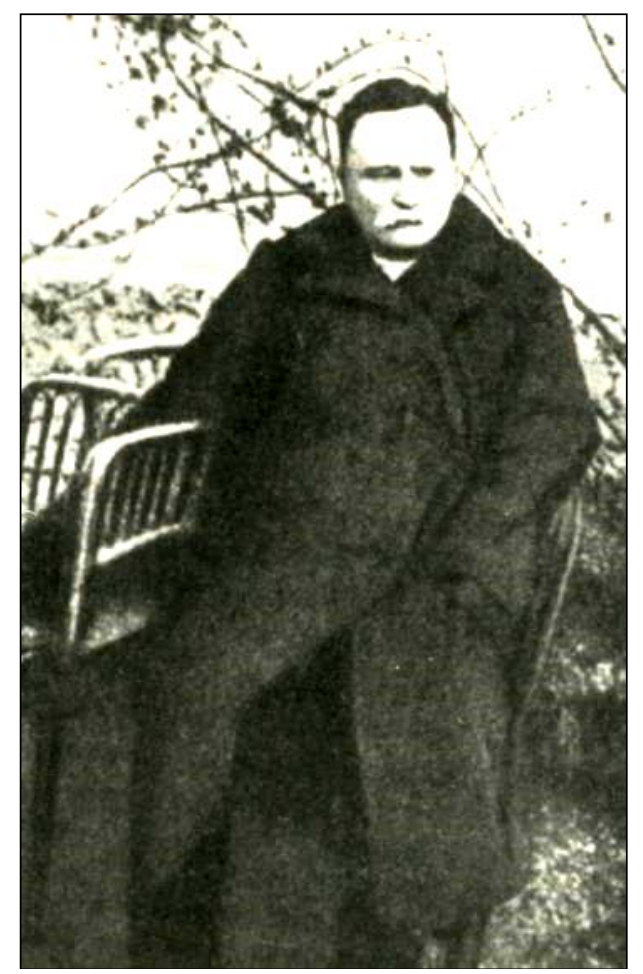

\section{Ivan Franko during the treatment in Lovran. Early March - early April 1909}

The first days of his stay in Lovran Franko had a positive effect on his health. As we can see, there are notes in the press and the words of his son Andryi, who wrote to K. Bandrivskyi on February 22, 1909: "I hope that in a short time Dad's hands are completely straightened... Dad thinks to stay here for a month and a half. If Dad's are straightened up even sooner, we would return to Lviv before time". A. Franko also comforted K. Bandrivskyi with another pleasant news: "Everything that Dad used to say about spirits is now slowly disappearing", 64 .

But despite the good news, we also see the anxiety of Franko's son and the worries of paternal health. In particular, he notes that "Dr. Eder ascertained the atrophy in his hands as a result of the improper circulation of blood, which had already been eliminated in part... The trouble is that the father now has a very large appetite for wine (Portwein) and to dishes with sugar. Dr. Eder explained to Mrs. Romanchukova [a keeper of the Central Hotel], due to her advise

${ }^{64}$ Франко А. Лист до К. Бандрівського від 22 лютого 1909 р. з Ловрана. І. Л. Ф. 3. Спр. 2490. С. 65. 
dad applied for help to Dr. Eder, that wine and sugar can cause his death. And it is only with such distress that I and Mrs. Romanchukova are able to deprive my dad from wine and sugar" ${ }^{\text {"65 }}$.

It should be noted that Lovran, where I. Franko was treated, in his article "From the Adriatic coast" N. Kybalchych states, is distinguished by a gentle climate, healing springs, a play of bright colors, tall old houses that were erected in stone which had the ability to shimmer in the sun with light blue, and in the shade with dark blue, light green chestnut leaves against a background of red earth, and finally with beauty of local streets along which "two can not go side by side, and the other, the socalled broad, walking, reaching the walls with both hands".

In spite of this, the life in Lovran passed monotonously, reminding the life of Ukrainian small county towns or large towns. The inhabitants of Lovran in general belonged to the typical bourgeoisie, among whom the shopkeepers, the owners of villas, houses and vineyards were distinguished ${ }^{66}$.

Lovran itself is very old, since it originated from the historical Roman family Agrippa, who built a summer house here. The name of this city was derived from the fact that its hills were covered with dense laurel forests. According to P. Karmanskyi, "Lovran" of I. Franko's time "counts with about 4,000 inhabitants belonging to it Ica, San Francesco, Olwitz and Tulisevitz, of which some, especially the local "aristocracy" are Italians, and democracy, that is, further nooks, workers and fishermen, make up Croats ... Italians, although they are in the minority, feel the masters, neglecting their neighbors, Slavs, mock at their songs and sometimes come to antagonisms that lead to beatings. Proud Italians go over the sea shore, singing a song proudly: "Nostra terra italianaPorta nome di Lovrana" - but in the meantime in the local church - as a taunt, see lonely anomaly in the Roman church, Mass is served by live Croatian language ....67.

${ }^{65}$ Там само. С. 65-66.

${ }^{66}$ К[ибальчич] Н. 3 побережжя Адріатики. Lovrana: Рада. Газета політична, економічна і літературна. К., 1908. № 67. 20 марта (2 квітня). С. 1.; К[ибальчич] Н. Побережжя Aдріатики. Lovrana. II.: Рада. Газета політична, економічна i літературна. К., 1908. № 99. 30 апріля (13 травня). С. 3.

67 Карманський П. Льоврана: Дїло. Ч. 126. 8 червня. Львів, 1908. С. 1. 
Typical for Lovran at the time was that the "foreigners" came here from the farthest countries for two seasons: spring, which lasted from February to May, and summer, which included the period from July to October. First of all, the climate was more appealing to tourists than Abaci. The average annual temperature in Lovran was $+14^{\circ}$ Celsius. Snow was rare, winter temperatures almost never dropped to zero, and on the contrary, sometimes rising to $+18^{\circ}$ Celsius. Lavran water contains many mineral particles, of which $30 \%$ is salt. The air, on the one hand, is filtered by the sea, and on the other by the scents of the mountain flora. The greatest pride of that time was pension "Central" with the adjacent "Villa Najade", which were on the sea shore under the "council of pleasant hostess Mrs. Romanchukova"68.

It was here, in the villa "Central", that the Frankos found apartment, as it is evidenced by the letters sent from there by Franko to N. Kybalchych ${ }^{69}$. The first letter from Lovran to N. Kybalchych I. Franko sent on 2 March, 1909. It said that already passed a year from the time that he saw her in Lviv. According to him, this year was the worst in his life and was spent "among such patience and anguish and full of such strange adventures that may not be destined for anyone in the world to experience" ${ }^{30}$. The author further writes that he has given by the Almighty to get out of this grief healthy, and he is the first time for the whole year hopes for a "decisive turn for better". The addressee emphasizes that he cannot tell all the details of what happened to him, but only mentions that "spent last March and April in Lypyk in Croatia" he intended to come to N. Kybalchych after treatment in Lovran. Prevented it the adventure that happened to him on April 21, 1908 in Lypyk and as he classifies it "a terrible catastrophe" for himself, as it ended for him "three month disease, three-month compulsory lying in one of Lviv's establishment for incurable patients, and lying ended with complete paralysis of both his hands. From that time, the scholar points out, he was in so much trouble that he was forced to leave from

${ }^{68}$ Там само.

${ }^{69}$ Франко І. Лист до Н. К. Кибальчич від 2 березня 1909 р. з Ловрана «Villa Central»: Франко I. Зібр. тв. Т. 50. С. 368.; Франко І. Лист до Н. К. Кибальчич від 9 березня 1909 р. з Ловрана «Villa Central»: Франко I. Зібр. тв. Т. 50. С. 370.

70 Франко І. Лист до Н. К. Кибальчич від 2 березня 1909 р. з Ловрана «Villa Central»: Франко I. Зібр. тв. Т. 50. С. 368-369. 
February, 1909 "to save his health and ended up in Lovran"71. Ivan Franko finished the story with some considerations about N. Kybalchych' literary activity and stated that he would be very glad when she wanted to write him a few words ${ }^{72}$.

The answer was not delayed. N. Kybalchych wrote to I. Frankov in Lovran on March 6, 1909. She sincerely thanked about the letter and remarked: "I would very much like to talk to you and regret that it can not be done in letters, especially since I cannot write them" ${ }^{, 73}$. The author further emphasizes that I. Franko is being very lacked in Ukrainian literature and hopes that he will fully regain his strength "in quiet and good Lovran,"74.

Also N. Kybalchych tells I. Franko about her collaboration with the journal "The Future", the editorial board of which often disagrees with her thoughts ${ }^{75}$. As for her collaboration with "the Literary and Scientific Bulletin", she notes that after returning her unpublished manuscripts, she does not consider herself an associate. The writer further writes: "It is difficult for me because I have been writing there for more than eleven years and have got used to it" 76 .

In concluding her letter, the author asks I. Franko how much time he will spend on treatment in Lovran and notes that sometimes she writes a lot and sometimes does nothing: "Sometimes life is so depressing that Iu do not have to go for literature. Thus, if I have nowhere to print, what is the reason of writing all the manuscripts or burn them. Better let them burn unwritten in my soul",77.

The scholar did not advised N. Kybalchich to cooperate in the journal "The Future", because he considered his editor and assistants insufficiently experienced for such work and said that the newspaper: "utterly frivolous and issued by people completely immature and unprepared for what they have to do and issued too much without any express program". But despite the comments he made, he emphasized:

\footnotetext{
${ }^{71}$ Там само. С. 369.

72 Там само.

${ }^{73}$ Кибальчич Н. Лист до І. Франка від 6 березня [1909] р. І. Л. Ф. 3. Спр. 1630. C. 559.

74 Там само.

${ }^{75}$ Там само. C. 560.

76 Там само. С. 561.

77 Там само.
} 
"I do not mind that you have included your literary works in that journal, although from the first four issues I see that the editorial, apart from the hot words in the editorial correspondence, has little desire to print your works" "78 . I. Franko was very surprised that the editor of "The Literaryscientific Herald" returned N. Kybalchych' manuscripts. He said: "I had a conversation with Prof. M. Hrushevskyi about editing "the Herald" in 1908 and about the outrageous things that were published there throughout the year, and he knows only one thing to say, that nothing better was not sent to him. I do not know what works you sent to him, but I still think that you could not write worse than Lesya Ukrainka, Hotkevych and both Hrushevskyis published there. I think that in such direction as it is, "the Herald can not go long, but I still have no idea how his reform can be accomplished ${ }^{79}$.

Completing the letter, she assures N. Kybalchych that he deeply sympathizes with her difficult life, but at the same time asks in no case to stop the literary work, "even if she has to keep the written works in the author's folder". Summing up, he emphasized: "From what I see now in Galicia and in Ukraine, I get the certainty that our literary production must go up strongly and that soon it will be possible to organize the centers of respectable and solid literary production in Lviv and Kyiv. In that case, I think that your literary works, both printed and non-printed, will find a wider course and will be better paid than ever" ${ }^{\prime \prime 0}$.

In response, N. Kybalchych sent a letter to Ivan Franko, stating: "Dear Sir! Thank you very much for rememvering me. I wish you, as always, the best!"

From the letter of I. Franko to N. Kybalchych dated March 9, 1909, we see that he lacked money for treatment, which was very expensive for him. His friends and colleagues in Lviv knew this. In particular, on April 2, 1909, the editorial board of the newspaper "The Galychanyn" put on its front pages a note already entitled "Honorary Gift for I. Franko", which read: "Ukrainian-Radical Ambassador of the seim Dumka summons in the "Public Voice" the Ukrainian society to collect

\footnotetext{
78 Там само.

${ }^{79}$ Там само. С. $370-371$.

${ }^{80}$ там само. С. 371.

${ }^{81}$ Кибальчич Н. Листівка до І. Франка від [середини березня] [19]09 р. І. Л.
} Ф. 3. Спр. 1630. С. 563-564. 
for the honorary gift of 300,000 rubles presented to the writer Dr. Ivan Franko. The amount can be collected in the way Mr. Dumka made calculations: 30 million people should donate one geler. To send the money to the Ukrainian society and millions of Russians can also be added and, of course, to make Rechnung ohne Wirt" ${ }^{\text {" }}$.

Lviv continued to collect donations for Ivan Franko's treatment. The newspaper "The Dilo" prints another list of benefactors who contributed to a good cause, adding a certain amount in crowns "Myhailo Liskevych, Vienna 6, Pavlo Durbak 20, Yosyp Pavlinskyia 10, H. U. Lviv 1, Olga Shukhevych Tyshkivtsi 10, Teodozij Chychka 2, Dr. Tadei Solovij 50, Branch of the Russian Pedagogical Society, Zbarazh 10, Ivan Ukrainskyi 55.50, Ivan Trush, Lviv 15"83..

Franko remained on treatment in Lovran to mid-April, 1909, on 23 April this year, the newspaper "The Dilo" reported: "As "The Kyivski Visti" inform Dr. Ivan Franko hostes in Kyiv now, who arrived there last week from Lviv. The famous writer of ours is not completely overcome after the grave misery that he had last year. His hands are sparred so that he does not move his fingers at all. Still, he retained a keen interest in science, visiting libraries in Kiev, mainly interested in Slavic philology. The Honorable scholar will stay in Kiev for one more week and then return to Lviv" "84. And three days later, on April 26, the same newspaper in the literary news added that Ivan Franko had recently translated from Latin the famous novel "Amur and Psyche", and this translation will be published in "the Universal Library" in Lviv" ${ }^{85}$. The history of this translation was rather extraordinary. The translation of Apulian story of Amur and Psyche because of the illness of Franko made with the help of his sons. According to Taras Franko, this translation was first made by his brother Andrew. I. Franko himself intended only to make corrections to this translation, but then left this work and began to dictate his own translation, which later came out in print. In this case, the scholar could not be satisfied by Andrew's text

${ }^{82}$ Почетный даръ для Ив. Франка: Галичанинъ. Львовъ, 1909. 2 (15) апр[і]ля. C. 3.

\footnotetext{
${ }^{83}$ Новинки. Для хорого письменника.... Дїло. Ч. 75. 6 цьвітня. Львів, 1909. С. 3.

${ }^{84}$ Новинки. Франко в Київі: Дїло. Ч. 86. 23 цьвітня. Львів, 1909. С. 3.

85 Лїтературні новини: Дїло. Ч. 88. 26 цьвітня. Львів, 1909. С. 4.
} 
because of the "amateurish approach to business". The same was with the Foreword to this book ${ }^{86}$.

\section{CONCLUSIONS}

The Croatian resort towns of Lypyk and Lovran have benefited to I. Franko mainly in the treatment of illness. During his stay, he worked productively. New poetries, translations, works, etc. appeared, although they were of a specific nature. Here he got acquainted with the local colors, which in the future he reflected in his work. Although the scholar returned from Lypyk and Lovran not cured, he did not fall spiritually and continued to fight with his illness, even in strange ways. The relevant in the context will be the words of the contemporary scholar V. Doroshenko, who emphasized that "sick Franko did not stop being a giant, did not stop impressing us with his hard work and productivity. A severe illness that could bring others out of the world in a very short time, although it broke Franko extremely strong physically and mentally, but did not kill him, and he lived and worked for ten whole years and, despite all the aforementioned consequences of the aforementioned illness, gave not one good thing for us. He worked briskly, somehow even feverishly, detailing on each manuscript when exactly he started it and when he finished, as if he wanted to show that he was not ill at all, but healthy and able to work ${ }^{87}$.

\section{SUMMARY}

The study presents the connections of Ivan Franko with the resort towns of Croatia - Lypyk and Lovran. The relevance of this work is conditioned first of all by the fact that since the independence to the present day Croatia foam vpratsyuye from Ukraine in various fields. One and the most important evidence of this is the opening of the monument to Ivan Franko in $\mathrm{L}$ and $\mathrm{n}$ and $\mathrm{k}$ in in March 2011. The Ukrainian community in Croatia was encouraged to take such a step in 1908.

86 Якимович Б. Іван Франко - видавеиь: Книгознавчі та джерелознавчі аспекти. Львів, 2006. С. 459.

87 Дорошенко В. Іван Франко в моӥх спогадах: Гнатюк М. упор. Спогади про Івана Франка. Львів, 1997. С. 405. 
In this view, the study found that the Croatian city of Lypyk became a city of hope for the Ukrainian genius, where he came for treatment and stayed there for about a month. In 1909, Franko was treated in another Croatian resort town - Lovran. Although the scholar returned from them not cured, but still he will not see and hear there, he found a significant reflection in his poetry, literary works and so on.

It was also found that not many letters came from I. Franko from Lypyk and Lovran and vice versa. His correspondents were O. Franko, daughter Anna, doctor L. Kossak, well-known Ukrainian figures of the time - M. Hrushevskyi, V. Domanitskyi, F. Vovk, V. Hnatyuk, and N. Kibalchich. The main topic of correspondence was Franko's illness, but, in general, the information about scientific interests and reflections of the scholar prevailed.

It is proved that while being treated in the mentioned resort towns, Ivan Franko was studying the cultural life of the Croatian people. At the same time, he made extensive use of the achievements of the Slavic science world, tried to develop the traditions of leading Slavic scholars, and offered his model of development and strengthening of UkrainianCroatian relations.

\section{REFERENCES}

1. Всячина: Галичанинъ. Львовъ, 1909. 11(24) февраля. С. 3.

2.Гнатюк В. Франко в Липику: Іван Франко у спогадах сучасників / Упоряд. передмова та примітки О. I. Дея. Львів: Каменяр, 1972. Кн. II. С. 247.

3.Грушевський М. Недуга д-ра Івана Франка: Літературнонауковий вістник. - Львів-Київ: 3 друкарні Наукового Тов. ім. Шевченка під зарядом К. Беднарського, 1908. Т. XLII. Кн. V. За май. С. 405-406.

4.До стану здоровля д-ра Ів. Франка: Рада. Газета політична, економічна і літературна. К., 1908. № 218. 24 сентября (7 листопада). С. 1.

5. Дорошенко В. Іван Франко в моїх спогадах: Гнатюк М. упор. Спогади про Івана Франка. Львів: Каменяр, 1997. С. 402-407.

6. Дорошенко Д. Останній побут Івана Франка у Київі (Сторінка із спогадів): Літературно-науковий вістник. Львів, 1926. T. XC. Кн. VII - VIII. За Липень - Серпень. С. 282-292. 
7. Кибальчич Н. 3 побережжя Адріатики. Lovrana: Рада. Газета політична, економічна i літературна. К., 1908. № 67. 20 марта (2 квітня). С. 1.

8. Кибальчич Н. Побережжя Адріатики. Lovrana. II.: Рада. Газета політична, економічна і літературна. К., 1908. № 99. 30 апріля (13 травня). С. 3.

9. Карманський П. Льоврана: Дїло. Ч. 126. 8 червня. Львів, 1908. C. 1.

10. Кибальчич Н. Лист до І. Франка від 6 березня [1909] $p$. І. Л. Ф. 3. Спр. 1630. С. 559-561.

11. Кибальчич Н. Листівка до І. Франка від [середини березня] [19]09 р. І. Л. Ф. 3. Спр. 1630. С. 563-564.

12. Коссак Л. Лист до І. Франка від 31 березня 1908 р. із Львова. І. Л. Ф. 3. Спр. 50. С. 352-353.

13.Літературні новини: Дїло. Ч. 88. 26 цьвітня. Львів, 1909. C. 4 .

14. Лозинський М. Складки на хорого письменника: Рада. Газета політична, економічна і літературна. К., 1908. № 243. 24 октября (5 грудня). С. 1.

15.Мельник Я. Бібліотека Івана Франка: Бібліотека Івана Франка. Науковий опис. У чотирьох томах. К., 2010. Т. І. C. 9-31.

16. Мельник Я. I остання часть дороги... Іван Франко: 19081916. Дрогобич: Коло, 2006. 439 с.

17. Мочульський М. 3 останніх десятиліть життя Івана Франка (1896 - 1916): Іван Франко у спогадах сучасників. Львів: Книжково-журнальне видавництво, 1956. С. 422-444.

18. Мочульський М. 3 останніх десятиліть життя Івана Франка (1896-1916): Гнатюк М. упор. Спогади про Івана Франка. Львів: Каменяр, 1997. С. 364-393.

19. Мочульський М. Іван Франко: Студї та спогади. Львів, $1938.210 \mathrm{c}$.

20.Новинки. Для хорого письменника...: Дїло. Ч. 75. 6 цьвітня. Львів, 1909. С. 3.

21.Новинки. Д-р Іван Франко...: Дїло. Ч. 37. 20 лютого. Львів, 1909. C. 4.

22.Новинки. Стан здоровля д-ра Івана Франка: Дїло. Ч. 28. 8 лютого. Львів, 1909. С. 3. 
23.Новинки. Франко в Київі: Дїло. Ч. 86. 23 цьвітня. Львів, 1909. C. 3.

24. Новинки: Дїло. Ч. 90. 21 цьвітня. Львів, 1908. С. 4.

25.Новинки: Дїло. Ч. 81. 11 цьвітня. Львів, 1908. С. 3.

26.Новинки: Дїло. Ч. 87. 18 цьвітня. Львів, 1908. С. 3.

27.Новинки: Дїло. Ч. 97. 28 цьвітня. Львів, 1908. С. 4.

28.Новинки: Дїло. Ч.101. 2 мая. Львів, 1908. С. 4.

29.Новинки: Дїло. Ч.143. 20 червня. Львів, 1908. С. 4.

30.Новинки: Дїло. Ч. 171. 1 серпня. Львів,1908. С. 4.

31.Почетный даръ для Ив. Франка: Галичанинъ. Львовъ, 1909. 2 (15) апр[i]ля. С. 3.

32. Франко А. Лист до К. Бандрівського від 22 лютого 1909 р. $з$ Ловрана. І. Л. Ф. 3. Спр. 2490. С. 65-66.

33. Франко I. Епілог: Франко I. Похорон. Поема. Львів: Каменяр, 2008. С. 52-54.

34.Франко I. Епілог: Франко I. Похорон: Франко I. Зібрання творів у 50-ти т. К.: Наукова думка, 1976. Т. 5. С. 87-89.

35.Франко I. Історія моєї хвороби / Публікація Ярослави Мельник: Парадигма / Інститут українознавства НАН України. Львів: Критика, 1998. С. 178-183.

36.Франко I. Історія моєї хвороби: Інституту літератури ім. Т. Г. Шевченка НАН України (далі - І. Л.). Ф. 3. Спр. 185.

37. Франко І. Лист до В. Гнатюка від 10 квітня 1908 р. $з$ Липика/ Публікація Ярослави Мельник: Парадигма. Зб. наук. Праць / Ін-т українознавства ім. І. Крип'якевича НАН України. Львів: Класика, 1998. С. 191-192.

38. Франко І. Лист до В. Доманицького від 2 квітня 1908 р. $з$ Липика / Публікація Ярослави Мельник: Парадигма. Зб. наук. Праць / Ін-т українознавства ім. І. Крип'якевича НАН України. Львів: Класика, 1998. С. 187-188.

39. Франко I. Лист до В. Доманищького від 27 березня 1908 р. з Липика / Публікація Ярослави Мельник: Парадигма. Зб. наук. Праць / Ін-т українознавства ім. І. Крип'якевича НАН України. Львів: Класика, 1998. С. 183-185.

40.Франко I. Лист до Льва Коссака від 31 березня 1908 р. із Липика: Франко І. Зібрання творів у 50-ти т. К.: Наукова думка, 1986. T. 50. C. 352. 
41.Франко І. Лист до М. С. Грушевського від 27 жовтня 1906 p.: Франко I. Зібрання творів у 50-ти т. К.: Наукова думка, 1986. T. 50. C. 299.

42. Франко І. Лист до М. С. Грушевського від [першої половини квітня 1908 р. із Липика]: Франко І. Зібрання творів у 50-ти т. К.: Наукова думка, 1986. Т. 50. С. 355.

43. Франко І. Лист до М. С. Грушевського від 24 березня 1908 р. із Липика: Франко I. Зібрання творів у 50-ти т. К.: Наукова думка, 1986. T. 50. C. 351-352.

44. Франко І. Лист до Н. К. Кибальчич від 2 березня 1909 р. $з$ Ловрана «Villa Central»: Франко I. Зібрання творів у 50-ти т. К.: Наукова думка, 1986. Т. 50. С. 368-369.

45. Франко І. Лист до Н. К. Кибальчич від 9 березня 1909 р. $з$ Ловрана «Villa Central»: Франко I. Зібрання творів у 50-ти т. К.: Наукова думка, 1986. Т. 50. С. 370-371.

46. Франко І. Лист до О. Ф. Франко від 31 березня 1908 р. із Липика: Франко І. Зібрання творів у 50-ти т. К.: Наукова думка, 1986. T. 50. C. 353.

47. Франко І. Лист до О. Ф. Франко від 6 квітня 1908 р. із Липика: Франко І. Зібрання творів у 50-ти т. К.: Наукова думка, 1986. T. 50. C. 353-354.

48. Франко І. Лист до Ф. К. Вовка від 2 квітня 1908 р. $з$ Липика/ Публікація Ярослави Мельник: Парадигма. Зб. наук. Праць / Ін-т українознавства ім. І. Крип'якевича НАН України. Львів: Класика, 1998. С. 189-190.

49. Франко І. Лист до Ф. К. Вовка від 20 лютого 1908 р. із Львова: Франко I. Зібрання творів у 50-ти т. К.: Наукова думка, 1986 . T. 50 . C. 351.

50. Франко I. Перехресні стежки: Франко I. Захар Беркут. Перехресні стежки. Оповідання. К.: Веселка, 2006. С. 177-462.

51.Франко О. Лист до I. Франка від 8 квітня [1908 p.] зі Львова. І. Л. Ф. 3. Спр. 1636. С. 37-38.

52. Франко-Ключко А. Рукописи Івана Франка в Канаді: (Лист із Липика, Югославія, та інше). Вінніпег, 1957. URL: http://library.kr.ua/elib/franko/franko-rukopis.html.

53. Франко-Ключко А. Рукопси Івана Франка в Канаді. 1. Листи: Для Тебе Тату / Упоряд, автор вступної статті й копентарів М. Шалата. К.: Ярославів Вал, 2010. С. 244-250. 
54. Чикаленко С. Іван Франко: (Уривок із споминів): Наша громада. 1926. Кн. 5-6. С. 17.

55.Якимович Б. Іван Франко - видавець: Книгознавчі та джерелознавчі аспекти. Львів: Б. в., 2006. 691 с.

56. Simper S. A century of health and sea bathing tourism in Lovran: one hundred zears from issuing the first therapz regulations (1909-2009): Acta med-hist Adriat. Lovran, 2009. № 7(1). S. 145-148.

\section{Information about the author:} Halyk V. M.

Candidate of Historical Sciences, Senior Lecturer at the Department of World History and Special Historical Disciplines,

Drohobych Ivan Franko State Pedagogical University 46, Lesi Ukrainky str., Drohobych, Lviv region, 82100, Ukraine 


\section{BELARUSIAN-UKRAINIAN ART RELATIONS OF THE SECOND HALF OF THE XIXth - EARLY XXth CENTURY}

\section{Hrytsenko H. Z.}

\section{INTRODUCTION}

The being of Ukrainian and Belarusian ethnic lands as a part of the Russian and Austro-Hungarian monarchy had an impact not only on their socio-economic, but also cultural and educational development and the character of relationships. The impact is exposed in different ways (by public policy, via personal relationships, etc.) was not similar. It was vivid in the sphere of culture, especially in education and science, in public life.

The specificity of contacting of related cultures gave rise to a variety of forms and means of assimilation of previous achievements of neighboring peoples. Culture that expressed the highest degree of national consciousness, the culture medium generated patriotic sentiments in neighbors, stepped the processes associated with the formation of national cultures. These interdependent processes were intense and peculiar Slavonic phenomenon - national revival.

It was culture that helped Slavs to announced themselves as original nations. Of course, this was reflected on the content and forms of their relationship, increased the interest in the history and culture of their neighbors. Language kinship, common objectives of socio-political development were the basis of their unity. Finding ways and forms of their rapprochement and cooperation led to the emergence of the concepts of Slavonic community and cohesion of Slavs. During this period, some Ukrainian public and cultural figures tried to support Belarusians in their struggle for their national identity. Educated officials, many of whom proved themselves as writers, artists, scientists, teachers and other workers in culture, supported lively contacts with their counterparts on different territories of the empire. Their relationships contributed not only to scientific researches, but also to reciprocal and enriching progressive ideas and were the impetus for the development of radical actions. 
Thus, since the end of XIXth - beginning of XXth century this process increasingly becomes two-sided, acquires the character of interaction. The relatively small process of interaction is traced in the field of art. The creative contacts between Belarusians and Ukrainians affected positively the development of performing and Fine Arts of two nations enriching them with new ideas, images, themes.

\section{The Relationships in the sphere of Performing Arts}

Performing Arts promoted strengthening and development of cultural relations. The beginning of Belarusian-Ukrainian theatrical relationship and their content filling assisted the activities of Ukrainian theatrical troupes that began to emerge in the middle of the XIXth century ${ }^{1}$. Somewhere they performed outside Ukraine, including Homel and Minsk. In the 50's of the XIXth century the troupe of M. Betljevskyi was touring the towns and cities of Grodno region. Belarusian theatrical culture was significantly activated by the creation of an amateur theater by V. Dunin-Marcinkevych in his estate Lyutsynka ${ }^{2}$. This enabled the solution of the problem of Belarusian National Theater, its own drama. It is known that V. DuninMarcinkevych traveled to Ukraine, in particular, to Kiev, accompanying his children during their concert activities ${ }^{3}$. In 1866 he wrote the comedy "Pinsk nobility" in the Polish dialect of the Ukrainian language in which he ridiculed the proud and dumb local nobles, as well as Russian bureaucrats.

The reciprocal theatrical links revived significantly due to the emergence of a professional theater in Ukraine (troupes of Kropyvnitskyi, Starytskyi, P. Saksaganskyi Sadovskyi, KarpenkoKaryi) ${ }^{4}$. As Ukrainian theater groups had no permanent place for

1 Ахрыменка П. Летапіс братэрства. Аб беларуска-украінскіх фальклорных, літаратурных і тэатральных сув’язях. - Мн., 1973. - С. 98.

2 Охріменко П. Шляхами братання(про українсько-білоруські театральнодраматичні зв'язки). - К., 1968. - С. 37.

3 Вінцэнт Дунін-Марцінкевіч і працэс міжславянскіх літаратурных узаемасувязяў. Матэрыяль V Міжнар. Ракаўскіх чытанняў, в Пяршаі Валожынскага раёна, 20 чэрвеня 2004 г. : насустрач 200-годдзю 3 дня нараджэння В. Дуніна-Марцінкевіча / [пад рэд. В. П. Рагойшы, М. В. Хаўстовіча]. - Мн., 2005. C. $36-40$.

\footnotetext{
${ }^{4}$ Охріменко П. Шляхами братання. - С. 42.
} 
creative work, then toured along different cities and countries including Belarus. They acquainted the viewers with Ukrainian theatrical art, the works of national drama, folk songs. Folk art of those art groups received recognition everywhere they performed.

In unpublished letters by Eliza Ozheshko to the Polish scholar Yan Karlovych we find interesting observations about of Ukrainian theater. In the letter dated the 18 th of December 1887 from Grodno E. Ozheshko wrote: "the group of malorus (Ukrainian) actors came to Grodno ... saw the comedy by Shevchenko "Nazar Stodolia" ... this scene in no way similar with any other under the sun, the form is primary, all is beautiful, sincere, grateful...",

The tours of the troupes by M. Starytskyi attracted many Belarusian cultural figures. Belarusian viewers always met artists as expected and precious guests. For example, the newspaper "Minskyi Lystok" (18861894), published twice a week, on August 5, 1888 reported: "The expected guests have arrived. There were only two plays, but they gave us confidence that M.P. Starytskyi's troupe stay would leave a bright page in a modest chronicle of our scene. We warmly welcome our dear guests, and let their short stay be for hapiness"6.

The Starytskyi's touring of the troupe caused a lot of reviews and the appearance of several works of art. Ya. Kupala noted that Belarusians should have their own plays - both comedies and dramas ${ }^{7}$. The prominent Belarusian poet Ya. Luchyna, who wrote about farmers' life, worked much on the creation of the Belarusian theater modeled like Ukrainian. He studied the history of the old Belarusian theater, its repertoire. Under such conditions his work on Belorussian batleika appeared in print, in Polish ethnographic magazine "Wisła", Theater circles and amateur theaters were formed in a number of cities, towns and even villages in Belarus. They were in educational institutions, state railway stations, intellectual clubs. The emergence of comic opera “A peasant woman" by V. Dunin-Marcinkiewicz 9 meant a step forward

5 Orzeszkowa E. Oteatrze Ukraińskim // BiuletynPolsko-Ukraiński: tygodnikilustrowany. - Warszawa, 1934. - № 9. - S. 9.

${ }^{6}$ Ахрыменка П. Летапіс братерства. - Мн., 1973. - С. 100.

${ }^{7}$ Шарахоўскі Я. Пясняр народных дум. - Мн., 1970. - С. 73.

${ }^{8}$ Ахрыменка П. Летапіс братэрства. - С. 102.

9 Бэндэ Л. Першая беларуская опера // Літаратура і мастацтва. - 1961. 7 сакавіка. 
in the development of Belarusian dramaturgy, its genre renewal and attempts to embark on a professional career. It came out of print and was staged when only the People's Theater and its genres such as interlude and school drama existed in Belarus ${ }^{10}$. Since the number of Belarusian plays at that time was small, theatrical amateurs used the works of Ukrainian, Russian and Polish writers. Ya. Luchyna also tried to write plays, as the evidence is a small piece of his work on the theme of peasant life. He underlined the closeness between the Ukrainian and Belarusian peoples, highlighting the similarity of their fairy tales and songs ${ }^{11}$.

The tour of the troupe of M. Starytskyi became the basis on which the national repertoire of the Belarusian stage expanded and the creation of the Belarusian national theater took place.

The clear indication of this can be P. Karnytskyi's article "To the performances of maloruskyi troupe" dedicated to the tour of Ukrainian artists under the direction of Starytskyiin Belarus (1888). P. Karnytskyi started his article with the words, full of deep respect for theatrical, musical culture of Ukraine. He wrote enthusiastically about the multifaceted activities of M. Starytskyi, an educator and mentor of Ukrainian actors, emphasized not only on great skill of the troupe, but on profound nationality of the performances. P. Karnytskyi underlined the organic confluence of Ukrainian theater with folk art, characterized the Lysenko's music as the highest stage in the development of folksong culture of Ukraine.

Subsequently Ukrainian troupe of M. Kropyvnytskyi visited Belorusia that gave the performances for commoners, and the audience of Gomel, Bobruisk. The repertoire of the troupe of Kropyynitskyi included the plays by I. Kotliarevskyi, H. Kvitka-Osnovianenko, T. Shevchenko, M. Starytskyi, already familiar to Belorusian viewers, and new works were included - "After revision", "Make a fool of oneself” by M. Kropyvnytskyi, "Fortuneless" by I. Karpenko-Karyi. The plays by M. Kropyvnytskyi "After revision", "Make a fool of oneself" were translated into Belarusian with a number of up to the point changes and additions in 1910-1911s. The events and characters of these works

${ }_{10}^{10}$ Ахрыменка П. Летапіс братэрства. - С. 198.

${ }^{11}$ Беларуская літаратура ХІХ ст. Хрэстаматыя / [naд рэд. Александровіча С. Х.]. Мн., 1971. - С. 251. 
were so close and clear to Belarusian viewers that often were perceived by them as their own, and for years did not descend from the Belarusian scene. Speaking of the comedy "After revision", a connoisseur of the culture of the Belarusian people Yu. Karskyi noted: "With this play, first staged on February 12, 1910 in Vilno, the performances began in the Belarusian literature",

The Ukrainian theater performances were a high school of mastering for many Belarusian artists. While touring Belarus M. Kropyvnytskyi attracted to participate in mass scenes the members of amateur groups, artists of local theaters, students and schoolchildren. He carefully and persistently played every detail of crowd scenes, giving a valuable example for Belarusian theatrical youth. This is evidenced by, for example, the memoirs of the requisitioner of Minsk City Winter Theater S. Zelenkovych ${ }^{13}$. In the review, printed in the newspaper "The Minsk lystok", and it wasactually reported about one such case in the Ukrainian troupe touring in Belarus. Thus, in 1892 in the play of the troupe of M. Kropyvnytskyi "Nazar Stodolia" a local amateur A. Mykolaev performed successfully. ${ }^{14}$ It was noted in the newspaper that the amateur actor, still remaining a spectator, makes a crime against art, which would bring him great success. "The Minsk lystok" always concerned about the development of mutual relations of advanced cultures of Ukraine and Belarus.

In addition to the troupes of M. Starytskyi and M. Kropyvnytskyi, in the late nineteenth and early twentieth centuries other Ukrainian theater groups, troupes or individual artists also performed in Belarus quite often. According to K. Kasil, who worked as a controller in Minsk theatre (1906), the Belarusian audience enjoyed the theater company of M. Saksahanskyi greatly. Specifically, since 1 to 30 of November 1908, this troupe gave 34 performances in Minsk and since17 of September to 14 of October 1909-29 plays $^{15}$. Many supporters had the theater by Suslov, which during only 1907 gave 39 performances in Minsk ${ }^{16}$.

${ }^{12}$ Карский Е. Белорусы. - Мн., 2007. - T. 3. - С. 368.

${ }^{13}$ Охріменко П. Шляхами братання. - C. 38.

${ }^{14}$ Няфёд У. Беларускі тэатр. Нарыс гісторыі. - Мн., 1959. - С. 73.

${ }^{15}$ там само. - C. 110.

${ }^{16}$ Охріменко П. Шляхами братання. - C. 39. 
It is known that on the Belarusian territory, which was a part of the Vilensk province, during the years 1887-1902 numerous Ukrainian theater groups, including I. Vasilyev, P. Man'ko, V. Hrytsay, I. Khmara, S. Chesnovskyi, P. Nacilevych and others gave performances. In addition to the plays, they also organized concerts in which Ukrainian folk song played a leading role.

The Ukrainian drama plays occupied a prominent place in the repertoire of the first Belarusian professional troupe of Ignat Buinytskyi (1861-1917). It emerged on the basis of the amateur group (1907) which consisted of the family members and friends. One of its leading actors was O. Burbis, the head of the amateur group of Radoshkovych. The I. Buinytskyi's group performed in the towns and villages of the Dzvina district, in February 1910 participated in Belarusian vechornytsi (evening events) in Vilno ${ }^{17}$. The amateur Belarusian groups, being influenced by the troupe of I. Buinytskyi often organized performances and evenings where Shevchenko's word was heard. Ukrainian theatrical figures watched closely the rise and development of a talented theater by I. Buinytskyi ${ }^{18}$.

One of the forms of performing arts in Belarus was vechornytsi ${ }^{19}$. Their characteristic feature was that they were of Belarusian-Ukrainian character. Most often they took place in Gomel and Brest, where many Ukrainians lived. In particular, on the occasion of Shevchenko's holidays in 1908 in Mogiliv the play by T. Shevchenko "Nazar Stodolia" was staged. The Shevchenko's word was heard at illegal Ukrainian and Belarusian parties, which were organized by students and intellectuals dedicated to the anniversary of the poet in Vilno, Kiev, Kharkiv and other cities ${ }^{20}$.The conduction of such evenings was of great importance for mutual cultural acquaintance of the two nations, helped to strengthen the cultural ties between them.

17 Бульба А. 3 нашаго жыцьця. Аб беларускім тэатры // Наша ніва. - 1911.№ 39. - С. 485 .

18 Вігурска Г. Беларуская драматургія на Украіне // Беларусь. - 1955. - № 4. C. 26 .

19 Куліковіч М. Беларуская музика: Короткі нарыс гісторыі беларускага музычнага мастацтва. - Нью-Йорк, 1953. - Ч. 1. - С. 56.

${ }^{20}$ Ахрыменка П. Летапіс братэрства. - С. 91. 
The development of Belarusian-Ukrainian theatrical relations was accompanied by music ties at that time the integral part of almost every play was folk songs and dances. Thus, the performances of Ukrainian theater groups introduced Belarusian audiences with Ukrainian folk song.

Lack of national opera was one reason that Ukrainian opera began its stage life in Belarus, Ukrainian dramatic productions troupes. Such operas and operettas as "Natalka Poltavka", "Chornomortsi", "Night at Midsummer", "Drowned" by M. Lysenko, "Zaporozhets za Dunaem" by Hulak-Artemovskyí.

The newspaper "Minskyi lystok" noted the organic fusion of Ukrainian theatre with Ukrainian folk song, which is its soul. "Malorusia (Ukraine) is a country of songs.In the song of malorus (Ukrainian) his personal feelings, sorrow and joy; with a song he accompanies his old ancientrites .... Singing - the soul of malorus theater, without songs malorus life on the stage would be only half a life" 21 .

The Ukrainian musicians repeatedly gave concerts in Belarusian cities. In 1859 Ukrainian musician M. Sokolowskyi made a great tour of Belarus, during which he met and made friends with the BelarusianPolish poet Artem Verega-Darevsky (1816-1884). In October 1888 the concerts of the capella under the direction of Hordovskyi took place in Minsk. Belarusian critics singled out the performance of the folk songs "A Cuckoo", "Oh, mother, mother", the march from the opera by Lysenko "Chornomortsi" In March 1894 in the same concert hall the teachers of Lviv conservatorium had a concert. After 12 years the symphonic orchestra of Lviv philarmony had a great success there, conducted by the Czech musician L. Chelianskyi.

Musical ties were especially vivid in folk tunes ${ }^{22}$. This is due to similar historical destiny of two nations. In particular, in Belarusian and Ukraine great popularity had the songs, in which the struggle against Polish and other seigneurs was chanted. The example is "Bondarivna Song", which originated in Ukraine and spread rapidly in Belarus. There are many songs that are known in Ukrainian and Belarusian. These are "Oh by the lawn, by the lawn", "Overgrown paths" and others.

21 Ларчанка М. Славянская супольнасиь. - Мн., 1963.- С. 118.

${ }^{22}$ Белза И. Ф. О славянской музыке.Избранные работы. - М., 1963.- С. 112. 
At the beginning of XXth century, with the advent of professional theater in Ukraine and Belarus, the musical life intensified, gaining the reciprocal nature.

Despite the fact that the Ukrainian productions and concerts by all means were restricted, the new Ukrainian theater culture was penetrating deeply into the masses not only its own, but also neighboring nations, especially Belarus. This is due to the tours of Ukrainian theatre troupes in Belarus, amateur performances, concerts of Ukrainians who lived there.

Thus, in dramatic and theatrical life, Belarusians actively gained the best that was created in Ukraine. In particular, there were the plays by Ivan Kotliarevskyi, T. Shevchenko, M. Starytskyi, I. Kropyvnytskyi, I. Karpenko-Karyi in the repertoire of some Belarusian theaters, in which the life and aspirations of Ukraine people is deeply illustrated. It is clear that such works could not affect the repertoire of young Belarusian theater. At the same time the concerts of Ukrainian theaters on Belarusian territory played a positive role in the development of the Belarusian professional and amateur theater, affected the development of the Belarusian drama in general.

The cooperation with prominent representatives of Ukrainian theater approached Belarusian artists to the secrets of creative work and achievements of Ukrainian performing arts, contributed to the formation of the Belarusian theatrical culture.

The most notable connections were in the field of theater and music - they had a broad basis and lasting traditions. This was theater in Slavonic nations at the times of their statelessness was one of the speakers of national memory. A word in their native language sounded from the stage or the events of the heroic past were presented. Many talented singers and musicians began their work at theaters and later performed in Ukrainian and Belarusian theaters. The further development acquired an amateur scene in the form of Ukrainian vertep and Belarusian batleika. The formation of an amateur theater went through the development and enrichment of folk theater traditions in harmony with the achievements of a school, and later professional theater. The amateur theater was more accessible and democratic.

\section{The relationships in Fine Arts}

The beginning of the relations in the Fine Arts is connected with the names of Taras Shevchenko and Bronislav Zaleskyi (1820-1880). They 
met in exile in 1849.Created the genre sketches and landscapes ("The House of Kyrgyz", "A Rich Kyrgyz in yurta") by B. Zaleskyi in exile were close in the theme and style to the works of Shevchenko ("Bayhushi", "Kazashka Katya") and others. Subsequently, the acquaintance with Kobzar B. Zaleskyi called an extremely important event in his life ${ }^{23}$.

T. Shevchenko in personal meetings and conversations with B. Zaleskyi could learn a lot of new information from the life of the Belarusian people, their culture, folklore and literature. They were pen friends: 16 letters of Shevchenko to B. Zaleskyi and 10 letters of Zaleskyi to T. Shevchenko are preserved ${ }^{24}$.

T. Shevchenko sent him his individual paintings to Belarus, in estate Rachkovychi (in total 24 paintings were sent). Some of them were sent to Vilno and Lithuania for sale. The fact how B. Zaleskyi treated Ukrainian poet, how he appreciated him, we learn from the letter written by the artist in the Belarusian village Rachkovychi (Sluchchyna) after his return from exile: "Do not forget me! You willbe surrounded by many wiser and better people-wish so! But believe me, my dear friend, that few will be sincerer than I will love you."

In the letter to the artist on February 10, 1857 Shevchenko announced his plan to visit Belarus in the estate of the addressee: "Instead of Petersburg railway I choose a simple way - Smolensk or Vilensk - and get right to Rachkovychi ...and, in the arms of full happiness, rest ...". Unfortunately, these dreams did not come true. He was detained for six months by the police in Nyzhnyi Novgorod. T. Shevchenko have been sending to B. Zaleskyi his letters for several years, receiving in return the messages about life and culture of the Belarusian people.

As an apprentice of T. Shevchenko, the artist B. Zaleskyi was brought upon his ideas, perceived and felt with his heart the dialectical aesthetics - understanding the graphic as a means of knowledge and

${ }^{23}$ Федорук О. Т. Шевченко і Бр. Залеський. Демократичні засади графічного мистецтва середини XIX ст. (До проблеми художніх взаємин) / Перетин знаку: Вибрані мистецтвознавчі статті: У 3 кн. - К., 2008. - Кн. 3: Українська культурологія. Історія та теорія мистецтва. Постаті. Народна творчість. [Рецензії]. C. 164.

24 Львівська національна наукова бібліотека України ім. В. Стефаника, відділ рукопису. - Ф. 4688. - Оп. 1.- Спр. 303. - 22 арк. 
artistic upbringing of the people. He turns to Shevchenko's favorite, but the little spread the etching technique at that time.

B. Zaleskyi often painted the same objects as T. Shevchenko. Their relation to the figurative reality is filled with humanistic spirit, faith in the victory of the good over the evil. The proximity of pictures of two artists is not only in the common aesthetic grounds, and direct borrowing of Belarusian artist the specific compositions, colour scheme that is characteristic for a creative palette of T. Shevchenko. In this regard, "Manhyshlat Garden" of the artist is an analogy with Shevchenko's etching "In Kiev"25. Thanks to the efforts of B. Zaleskyi not small number of paintings by Shevchenko appeared in Belarus and got included into the local art collections. In 1865 B. Zaleskyi published them in an album of etchings. A direct continuation of Shevchenko's "Picturesque Ukraine" was the album B. Zaleskyi "The Life of Kyrgyzsteppe" in which he realized his democratic views, with sincere sympathy reacted to the images of life and nature of Kazakhs ${ }^{26}$. The etchings of B. Zaleskyi reflected the overall picture of the development of creativity towards a realistic reflection of reality. The distribution of Shevchenko's works in Belarus, their introduction to Belarusian art circles could not but affect the works of local artists. Therefore Shevchenko, and to a certain extent B. Zaleskyi made a corresponding impact on the Belarusian painting.

The thematic similarities with the artistic works of Shevchenko are traced in a Belarusian artist and writer of the late XIXth - early XXth century Karus Kaganets (real name Kasymyr Kostrovytskyi, 1868-1918) ${ }^{27}$. In his works he focused on folk art. His graphic household composition "At the Crossroads", "Belarusian lirnyk", the central place in which is taken by the image of kobzar-lirnyk, no doubt, influenced by the works of Taras Shevchenko ${ }^{28}$. The picture

25 Федорук О. Т. Шевченко і Бр. Залеський. Демократичні засади графічного мистецтва середини XIX ст. / О. Федорук / Перетин знаку: Вибрані мистецтвознавчі статті: У 3 кн. - К., 2008. - Кн. 3. - С. 166.

${ }^{26}$ Там само.- C. 169.

27 Максім Багдановіч. Энцыклапедыя / [под. рэд. М. В. Труса]. - Мн., 2011. C. 256.

28 Исторические корни дружбы и единения белорусского и украинского народов / [под ред. Кондуфор Ю. Ю.]. - К., 1978. - С. 112. 
"Belarusian lirnyk" by K. Kaganets reflects an everyday scene of contemporary Belarus ${ }^{29}$.

The embodiment of cultural relations of Ukrainian and Belarusian peoples became the creative biography of a Belarusian by origin, a famous sculptor and artist Mychailo Mikeshyn (1836-1896), which is associated with the name of Taras Shevchenko. Adopting of social and civil and creative experience of $\mathrm{T}$. Shevchenko by progressive Belarusian figures was grounded, as noted by M. Mikeshyn, on that "the figure of Taras Shevchenko with his selfless love for his native land, that has kept these high feelings under the irrepressible oppression of various moral humiliations, which his life was so rich, could not but evoke passionate sympathy ..." ${ }^{30}$. M. Mikeshyn highly valued T. Shevchenko before his return from exile, was reading "Kobzar" and illegal works, which were distributed among students in many lists. The personal acquaintance strengthened the appreciation of the young artist by T. Shevchenko, it caused interest of his activity and creativity.

In particular, for M. Mikeshyn as for many other artists, who tried to be useful by their life and work to their native people, in the face of $\mathrm{T}$. Shevchenko was brought "such type of purely national poet, even to whom neither before him nor after him and to our time, I personally did not know not only in Ukrainian but even in Slavonic peoples" ${ }^{31}$.

The Belarusian artist met T. Shevchenko in 1858 in the house of a sculptor F. Tolstoy and during the last three years of life of Ukrainian poet visited his apartment for many times. According to M. Mikeshyn's word, their relationship turned into "if not in friendship, then in very close relations". T. Shevchenko's entrust and sympathy to M. Mikeshyn was explained by his Belarusian origin. T. Shevchenko visited the studio of a young artist who painted a portrait of him for "Kobzar". This friendship of a young artist with the experienced revolutionary fighter beneficially effected M. Mikeshyn, helped to shape his democratic outlook. According to the artist, "neither folk lira of our Slavic poets

${ }^{29}$ Там само. - C. 113-115.

30 Кабржыцкая Т. В., Рагойша В.П. Карані дружбы. Беларуска-украінскія літаратурныя узаемасувязі пачатку ХХ ст. - Мн., 1976. - С. 116.

31 Ахрыменка П. Летапіс братэрства. - С. 97. 
haven't exerted upon me such a deep and good impression as Shevchenko's works ...."32.

M. Mikeshyn showed great interest in the life of Ukrainian people, its history. Numerous drawings on the topics from Ukrainian life, illustrations to M. Gogol's stories, to the book by Rohova "Bogdan Khmelnytskyi" and others testify this ${ }^{33}$.

As a sculptor M. Mikeshyn wanted to create a monument to T. Shevchenko and attempted to display the image in a monumental sculpture $^{34}$. So, shortly after the death of T. Shevchenko M. Mikeshyn illegally introduced to the already approved project by the tsar "The Millennium of Russia" the names of Taras Shevchenko and M. Gogol for their image in bas-relief on the pedestal of the monument. The government banned it. When this attempt failed, the author wrote to Tsar Alexander I : "Shevchenko ... in understanding the restoration of the beautiful word has done more for Malorusia than any other our poet ... By depicting him, we affirm the national pride of the people, demarcate themselves from the descendants' complaints as to our cold treatment of a single poet of Malorusia" 35 . After a few years, working on a project of the monument to Bogdan Khmelnitskyi in Kiev (18771888), M. Mikeshynplanned to hold in front of the rock that served as a pedestal of the monument, in the form of the image of kobzar T. Shevchenko, surrounded by peasants. "On the sides of Kobzar" he wrote, "there is a group of peasants: big, white, little and red rusives..."36. But this attempt also failed.

The story about installation of the monument to Bohdan Khmelnytskyi on Sophia Square in Kyiv in 1888, is full of dramatic pages of continuous intervention of officials and church in the interpretation of the image of Khmelnytskyi, the choice of location for monument's installment ${ }^{37}$. It turned out so that M. Mikeshyn was not invited to the opening of the monument.

\footnotetext{
${ }^{32}$ Ахрыменка П. Летапіс братэрства. - С. 100.

33 Дробаў Л. Н. Беларускія мастакі ХІХ стагодзя. - Мн., 1971. - С. 32.

${ }^{34}$ Українська скульптура 2 пол. ХІХ - поч. XX ст. / [під ред. Німенко А. В.]. K., 1963. - C. 31.

35 Там само.- С. 33.

${ }^{36}$ Національна бібліотека України імені В. І. Вернадського. Інститут рукопису. Ф. 10. - Оп. 1. - Спр. 1095. - Арк. 4.

37 Там само.
} 
The thought about the display of the Ukrainian poet in sculpture didn't leave the artist. He was trying to finish his intention when designing the monument to Alexander II and Catherine II, or proposed a separate opinion about the most grandiose monument to T. Shevchenko, then painted his portraits, or showed his illustrations to his immortal works. Thus, in 1894, he told V. Mihnevych: "I sit day and night creating a colossal 4 feet portrait of $\operatorname{Taras}^{38}$. M. Mikechyn, according to O. Myrovych (in unpublished memories "The Shevchenko's friends") "was unchangeable organizer of Shevchenko memorial days" 39 .

Thus, in 1909 in Gomel the performance took place, the fee from which were taken to the fund of the construction of the monument to Taras Shevchenko in Kiev. In February,1911 the committee of T. Shevchenko monument's installment turned to city counsil, Pinsk in particular, asking for help. Pinsk Council considered the apply ... in April and the posted the assignation of 3 rubles. The citizens were indignant at this and collected money. In the same way the money were collected in Minsk, Vitebsk, Mogilev and other cities and villages of Belarus $^{40}$. The activity of the Belarusian sculptor to honor of Taras Shevchenko as if symbolized the Belarusians love and respect to a great Ukrainian poet.

Some time there lived and worked in Ukraine Belarusian by origin Napoleon Orda (1807-1883) - an artist-ethnographer and historian of architecture, whose work is connected with Polish, Belarusian and Ukrainian cultures ${ }^{41}$. It is interesting for us that most of the art works the artist performed in Ukraine, despite the fact that already an elderly man, with pencils, watercolors and everything necessary for this type of work he walked on foot almost all current Kyiv, Volyn, Rivne, Zhytomyr, partially Lviv, Khmelnytskyi, Vinnytsia, Cherkasy and Ternopil regions. He used to draw in a pencil, adding watercolor, sepia, gouache. For example, in the book "The Sources of Cultural Relations" is noted: "While travelling along Ukraine, N. Orda planned a series of pictures

${ }^{38}$ Ахрыменка П. Летапіс братэрства. - С. 76.

39 Ахрыменка П. Тарас Шаўчэнка і Беларусь. - Мн., 1969. - С. 119.

40 Національна бібліотека України імені В. І. Вернадського. Інститут рукопису. - Ф. 10. - Оп. 1. - Спр. 1095. - Арк. 5.

41 Березіна I. Архітектурна спадщина України у творчості Наполеона Орди: іконографія та принципи використання. - Кам'янець-Подільський, 2009. - С. 123. 
with the images of architectural places.They are now stored in Krakiw National Museum grouped in a series of "Podilsk", "Kyiv", "Volyn". Most of the works are dated (specified month and day) 18731874. These views show a peculiar manner of N. Orda - a passionate promoter of historic architectural places ${ }^{42}$. Thus, the artist was a fixer of architectural heritage that was linked with admiration of rich historical antiquity, landscape and architectural views, assembly monuments, numerous castles and churches, monasteries and churches.

$\mathrm{N}$. Orda is important for Ukrainian art in that he has led to the development of veduta on Ukrainian lands, and its contribution to graphic culture is very large. This artist paid great attention to the depiction of landscapes and historical sites. A significant part ( 80 pages) of his drawings, are printed in Warsaw in seven editions of "The Album of landscapes of Poland" $(1873-1883)^{43}$ depicts Ukrainian architectural monuments and views of ancient cities of Ukraine (Izyaslav, Slavuta, Ostrog, Kremenets, Zhytomyr, Kyiv).

Along with the documentary fixation of architectural structures and complexes, the artist paid special attention to the works of landscape art. For example, traveling, N. Orda creates several compositions featuring landscapes of parks "Sofiivka", "Oleksandriya", capturing the natural features of natural landscape, sculptures and others. Such approach enriched the creative method of the artist and provided the ability to depict notonly an architectural object, but also the historical landscape, sculptural decoration and so on.

Thus, the works of N. Orda are unique genre of fine arts in which architecture, drawing, painting, history, country studies miraculously merged together. The artistic value of $\mathrm{N}$. Orda is he spread his understanding of historical and cultural monuments onto Ukraine, where his talent opened. In this sense, the patriotic mission of the done Ukrainian vedutas by $\mathrm{N}$. Odra is growing: they carry memory into the depths of authentic rather than not real centuries. The artist engraved his name to the history of Ukrainian art with the weight of his created works. That is why at the present stage of the development of Ukrainian

42 Федорук О. Джерела культурних взаємин: Україна у творчості польських художників другої половини ХІХ - початку ХХ ст. - К., 1976. - С. 100-101.

43 Національна бібліотека України імені В. І. Вернадського. Інститут рукопису. - Ф. 24. - Оп. 1. - Спр. 2037. - 1 арк. 
society the works of the artist have become an inexhaustible iconographic and informative source for historical and architectural science and art criticism.

It is known about long and fruitful work of an Ukrainian landscape painter Ivan Pokhitonov (1850-1942) in Belarus ${ }^{44}$. Belarusian landscape, poor life of people inspired the author to create such important works as "Washerwomen", "At the Prypiat" and others. In 1902 the artist created an exquisite scenery "Winter", "Potato gathering", "The Apiary".

Belarus is closely linked with the creativity of another Ukrainian self-taught artist - Oleksij Artyhanjev (1823-1892). Having graduated from Kyiv Institute of communications, O. Arty hanjev settled in his estate in Chernihiv and started learning to paint, working mainly with landscapes. In 80-90ss of the XIXth century the artist moved to Mohiliv province. This time is the peak period of his original talent blossom. There beautiful landscapes are painted to depict the nature beautifulness of Belarus ("Winter Landscape", "Evening", "View tin Mohiliv province", "After the Rain", etc.) ${ }^{45}$. His paintings, beginning with 1883 , permanently exhibited at academic travelling exhibitions. The works of Arty hanjev strengthened a realistic direction in the Belarusian landscape painting, development of art.

A significant contribution to the development of Ukrainian and Belarusian art of the beginning of the twentieth century is made by a Ukrainian artist Hnat Yaremenko (1874-1915). A son of a poor peasant from the village Bakhmach in Chernihiv region, $H$. Yaremenko showedthe ability to draw since childhood and was studied by an icon painter at Kiev-Pechersk Lavra. Subsequently, he was able to enter an art school of M. Murashko, after finishing it (1895), he was sent to St. Petersburg Academy of Art. Having graduated in 1904, H. Yaremenko moved to Minsk, where he lived until 1913, working as a teacher of graphic arts in a college. There he led an active creative life, was one of the organizers and participants of annual art exhibitions, opened drawing courses, where the poor children were taught free of

44 Дробов Л.Н. Живопись Белорусии ХІХ - начала XX веков. - Мн., 1974. C. 144.

Исторические корни дружбы и единения белорусского и украинского народов / [под ред. Кондуфор Ю. Ю.]. - К., 1978. - С. 122. 
charge. H. Yaremenko wrote a series of paintings of Ukrainian life ("A Ukrainian woman", "Evening", "A Girl"), which were exhibited in 1911 at the exhibition in Minsk.

The development of the Belarusian-Ukrainian relations art were activated by the study of some Belarusian artists in Ukraine. Their stay in Ukraine enriched them with new experiences, images, expanded the topicality of their works, which showed the life of Ukrainians. This is, in particular, the picture of Ya. Kruger "The Malorus Family" that was exhibited at one of the exhibitions in Minsk ${ }^{46}$, a series of sketches by L. Alperovych, made by him during his studies in Odesa. The artist with great sympathy depicted the images of ordinary workers - porters, fishermen, their daily hard work.

The expansion of mutual communication of artists, setting close contacts between them were promoted by art exhibitions and expositions, that were organized in Minsk and other Belarusian cities since he late nineteenth century. Thus, in Minsk, in addition to the exhibition of peredvyzhnyky in 1899 , local exposures we reorganized in 1902, 1904, 1907, 1908, 1911, 1912. In total, ten such exhibitions were held in Belarusin 1890-19177 . Besides the works of Belarusian artists, there were the works of Russian, Polish, Lithuanian and Ukrainian artists, including M. Pymonenko, P. Levchenko and others and also the paintings by local artists on Ukrainian themes (Ya. Kruger, H. Yaremenko).

Professional art shows in Belarus and present works of artists of different nationalities, attracted a wide range of Belarusian society, acquainted them with the life of other nations, traditions and achievements in the field of Fine Arts, activated the artistic ties between the nations.

\section{CONCLUSIONS}

A characteristic feature of the artistic relationship was uneven dimension of the development. The relations in the field of performing

46 Шчакаиіхін М. Мастак Якуб Кругер // Савецүкая Беларусь. - 1929. 5 сакавіка.

47 Українське мистецтво у міжнародних зв'язках. Дожовтневий період / [під ред. Савенок К. І.]. - К., 1983. - С. 176. 
arts were more intense than painting and sculpture. It can be explained by the nature of theatrical and musical groups which were touring constantly in different cities of the Russian Empire, including Ukraine. One of the principles of active development of theatrical and musical relationship between Belarus and Ukraine was the existence of high professionals (troupes of M. Starytskyi, M. Kropyvnytskyi, P. Saksaganskyi and others), which could not cause a response in the Belarusian society. The performances of these groups stimulated the development of national theater in Belarus, manifested the activities of the troupe of I. Bujnytskyi and others.

The development of musical connections paralleled with beginning of Belarusian-Ukrainian theatrical relations. Activation of musical life began with the advent of professional theater in Ukraine and Belarus. So theater - music links were viewed via a scene and repertoire.

Thus, we can say that the Ukrainian literature played an important role in the cultural - artistic life of the Belarusian people. In particular, it educated Belarusian readers and viewers, preparing them for the perception of works of their own national literature. Ukrainian drama contributed to the awakening of national self consciousness of Belarusians. The stage skills of Belarusian actors were formed on its best patterns. But the greatest merit was in awaking of creative forces of Belarusian people, stimulating the development of drama and theater.

The characteristic feature of the contacts in the field of painting is fragmentation. The work of Belarusian artists in Ukraine was determined first of all by the desire to get an art education, since at that time there were no such institutions in Belarus.

There were the facts of creative inter influences, the vivid example of this can serve as artistic interaction of $T$. Shevchenko and M. Mikeshyn, K. Kaganets, B. Zaleskyi and others.

Today, the artists learn to be citizens, with all the strength of the talent to serve their time, promote their creativity in solving of burning issues of our whole life, strengthen the bridges of friendship between nations, spread the ideas of humanism.

\section{SUMMARY}

The article explores the bilateral Belarusian-Ukrainian artistic relations at the period of their national-cultural revival. Namely, the characteristic peculiarities of interaction in the field of performing art 
are depicted. It is noted that mutual theatrical relations were activated due to the emergence of a professional theater in Ukraine (troupes of M. Kropyvnytskyi, M. Starytskyi, P. Saksaganskyi, M. Sadovskyi, I. Karpenko-Karyi),whichbrought the Belarusian artists to the secrets of creative work and achievements of Ukrainian performing arts, became the basis of the formation of Belarusian theatrical culture.

The beginning of the relationships is traced in the sphere of Fine Arts, associated with the names of Taras Shevchenko, B. Zaleskyiand M. Mikeshyn. The study of Belarusian artists in Ukraine contributed to the development of Belarusian-Ukrainian art, that explains the setting of personal contacts.

\section{REFERENCES}

1. Ахрыменка П. Летапіс братэрства. Аб беларуска-украінскіх фальклорных, літаратурных і тэатральных сувязях Павел Ахрыменка. - Мн. : Мастацкая літаратура, 1973. - 304 с.

2. Ахрыменка П. Тарас Шаўчэнка i Беларусь Павел Ахрыменка. - Мн. : Вышэйшая школа, 1969. - 125 с.

3. Белза И. Ф. О славянской музыке. Избранные работы / Игорь Фёдорович Белза. - М. : Советский композитор, 1963. $467 \mathrm{c}$.

4.Бэндэ Л. Першая беларуская опера / Лукаш Бэндэ // Літаратура і мастацтва (Мінск). - 1961. - 7 сакавіка.

5.Беларуская літаратура XIX ст. Хрэстаматыя / [пад рэд. Александровіча С. Х.]. - Мн. : Вышэйшая школа, 1971. - 375 с.

6. Березіна I. Архітектурна спадщина України у творчості Наполеона Орди: іконографія та принципи використання. [Монографія] / Інна Березіна. - Кам'янець-Подільський : Аксіома, 2009. - $128 \mathrm{c}$.

7.Бульба А. 3 нашага жыцця. (Аб беларускім тэатры) / Андрей Бульба // Наша ніва. - 1911. - № 39. - С. 485.

8. Вінцэнт Дунін-Марцінкевіч і працэс міжславянскіх літаратурных узаемасувязяў. Матэрыялы V Міжнар. Ракаўскіх чытанняў, в. Пяршаі Валожынскага раёна, 20 чэрвеня 2004 г.: Насустрач 200-годдзю 3 дня нараджэння В. Дуніна-Марцінкевіча / [пад рэд. В.П. Рагойшы, М.В. Хаўстовіча]. - Мн. : Права і эканоміка, 2005. - 88 с. 
9. Вігурска Г. Беларуская драматургія на Украіне / Галіна Вігурска // Беларусь. - 1955. - № 4. - С. 26.

10.Дробаў Л. Н. Беларускія мастакі XIX стагодзя / Леонид Никанорович Дробаў. - Мн. : Беларусь, 1971. - 109 с.

11.Дробов Л. Н. Живопись Белорусии XIX - начала XX веков / Леонид Никанорович Дробов. - Мн. : Высшая школа, 1974. - 334 с.

12.Исторические корни дружбы и единения белорусского и украинского народов / [под ред. Кондуфор Ю. Ю.]. - К. : Научная мысль, 1978. -235 с.

13.История искусства народов СССР в 9-и томах. Искусство первой половины XIX в. / [под ред. Костина М. М.]. - М.: Изд. Академии худужеств СССР. - 1981. - Т. 5-6. - 435 с.

14.Іванов В. Етнографічна експедиція по місцях, зв'язаних 3 іменем Т. Шевченка / Вячеслав Іванов // Народна творчість та етнографія. - 1961. - № 2. - С. 153-154.

15.Кабржыцкая Т. В., Рагойша В. П. Карані дружбы. Беларуска-украінскія літаратурныя узаемасувязі пачатку XX ст. / Татьяна Вячеславовна Кабржыцкая, Вячеслаў Пятровіч Рагойша. Мн. : Навука і тэхніка, 1976. -125 с.

16.Карский Е. Белорусы / Евфимий Карский. - Мн. : Беларуская энцыклапедыя, 2007. - Т. 3. - 665 с.

17.Куліковіч М. Беларуская музыка: Короткі нарыс гісторыі беларускага музычнага мастацтва / Михайло Куліковіч. - НьюЙорк : Б. в., 1953. - Ч. 1. - 62 с.

18. Ларчанка М. Славянская супольнасць / Міхаіл Ларчанка. Мн. : Выд. Міністэрства адукацыі БССР, 1963. - 237 с.

19. Максім Багдановіч. Энцыклапедыя / [под. рэд. М. В. Труса]. Мн. : Беларус. Энцыкл. імя П. Броўкі, 2011. -608 с.

20.Няфёд У. Беларускі тэатр. Нарыс гісторыі / Уладзімір Няфёд. - Мн. : Вид. АН БССР, 1959. - 380 с.

21. Охріменко П. Шляхами братання (про українсько-білоруські театрально-драматичні зв'язки) / Павло Охріменко. - К. : Мистецтво, 1968. - $136 \mathrm{c}$.

22. Orzeszkowa E. O Teatrze Ukraińskim / Eliza Orzeszkowa // Biuletyn Polsko-Ukraiński: tygodnik ilustrowany. - Warszawa, 1934. № 9. - S. 9.

23. Українська скульптура 2 пол. XIX - поч. XX ст. / [під ред. Німенко А. В.]. - К.: Вид. АН УРСР, 1963. - 220 с. 
24.Федорук О. Джерела культурних взаємин: Україна у творчості польських художників другої половини XIX - початку XX ст. / Олександр Федорук. - К. : Мистецтво, 1976. - 128 с.

25.Федорук О. Т. Шевченко і Бр. Залеський. Демократичні засади графічного мистецтва середини XIX ст. (До проблеми художніх взаємин) / Олександр Федорук / Перетин знаку: Вибрані мистецтвознавчі статті: У 3 кн. / Інститут проблем сучасного мистецтва Академії мистецтв України. - К. : Інтер-технологія, 2008. - Кн. 3: Українська культурологія. Історія та теорія мистецтва. Постаті. Народна творчість. [Рецензії]. - 416 с.

26.Шарахоўскі Я. Пясняр народных дум / Янка Шарахоўскі. Мн. : Маст. літ., 1970. -165 с.

27.Шчакаціхін М. Мастак Якуб Кругер / Мікалай Шчакаціхін // Савецкая Беларусь. - 1929. - 5 сакавіка.

\section{Information about the author: Hrytsenko H. Z. \\ Candidate of Historical Sciences,} Senior Lecturer of the Department of World History and Special Historical Disciplines, Drohobych Ivan Franko State Pedagogical University 46, Lesi Ukrainky str., Drohobych, Lviv region, 82100, Ukraine 


\section{VIOLATIONS OF "SOCIALIST LEGALITY" AT THE STATEMENT OF THE SOVIET ADMINISTRATION IN THE CARPATHIAN REGION OF OUN (1945-1954)}

\section{Ilnytskyi V. I., Haliv M. D.}

\section{INTRODUCTION}

With the exile of German invaders, the armed struggle on the open spaces of the Carpathian region of OUN did not stop. Restoration of the Soviet mode was followed by the formation of repressive retaliatory apparatus (in some cases came bodies were already created), which the local population perceived as the instrument of occupation. Therefore, the official soviet leadership constantly felt aversion of West Ukrainians. Some instances of cruel behavior were traced by certain representatives of authorities. Frank self-assurance of soviet leadership on the fast suppression of liberation movement was wrong. Strengthening of positions of the Soviet power in the region was due to the activity of repressive retaliatory apparatus.

The analysis of last researches. The question of the violations of socialist legality was researched by rather extended number of historical works and collections of documents. We want to distinguish complex researches on the history of the Ukrainian liberation movement of I. Bilas ${ }^{1}$, V. Ilnytskyi, A. Kentiya ${ }^{2}$, Yu. Kyrychuk ${ }^{3}$, A. Rusnachenko ${ }^{4}$,

1 Білас I. Репресивно-каральна система в Україні 1917-1953. Суспільнополітичний та історико-правовий аналіз. У двох книгах. Книга перша. Київ: Либідь ; Військо України, 1994. 432 с.

2 Кентій А. Нарис боротьби ОУН-УПА в Украӥні (1946-1956 рр.). Київ: Інститут історії України НАН України, 1999. 111 с.

3 Киричук Ю. Український національний рух 40-50-х років ХХ століття: ідеологія та практика. Львів: Добра справа, 2003. 464 с.

4 Русначенко А. Розумом $і$ серием. Украйнська суспільно-політична думка 1940-1980-х років. Київ, 1999; Русначенко А. Народ збурений: Національновизвольний рух в Україні й національні рухи опору в Білорусії, Литві, Латвї, Естонії у 1940 - 50-х роках. Київ: Університетське видавництво "Пульсари", 2002. 519 c. 
V. Sergiychuk ${ }^{5}$. However, a generalized research about the existence of this phenomenon in the Carpathian region of OUN is lacking. For this reason, the research's objective is to clear the main directions and scales of violation of socialist legality, to allocate the reasons.

\section{The notion, scales and punishments for violation of "socialist" legality}

In the course of the statement of the Soviet power and struggle against OUN and URA the Soviet repressive bodies broke so-called "socialist legality" massively. The notion "socialist legality" is rather conditional and wide. It can include, beginning from violations, continuous robberies, illegal detentions, falsifications of criminal cases, tortures, finishing with mass (illegal, extrajudicial) executions, rapes and so forth. The researcher of the Ukrainian liberation movement V. Sergiychuk considers that at separate stages of the struggle against the Ukrainian national liberation movement the Soviet mode did not pay attention to these types of crime, even encouraged them. Already on June 20, 1945 a commissar of internal affairs of the USSR V. Riasnyi by the results of the check of the activity of bodies of Administration of the Ministry of Internal Affairs in Drohobych region reported: "In a number of regional departments of Administration of the Ministry of Internal Affairs the lack of agency of operational work, the facts of gross violation of the Soviet legality, drunkenness, moral lapse of certain workers are elicited" . In number of conditions that promoted the commission by employees of retaliatory bodies of abuses and crimes, it is necessary to carry not only lack of control from the administration and chiefs, but also inefficient implementation of public prosecutor's supervision of their activity, and in most cases - its total absence. Quite often the workers dismissed from bodies of prosecutor's office in the USSR in the eastern areas and other republics for systematic violations

5 Сергійчук В. Тавруючи визвольний прапор. Діяльність агентури та спецбоївок НКВС-НКДБ під виглядом ОУН-УПА. Видання друге, доповнене. Київ: ПП Сергійчук M.I., 2006. 184 с.; Сергійчук В. Украӥнський здвиг: Прикарпаття. 1939-1955 pp. Київ: Українська Видавнича Спілка, 2005. 840 с.

6 Білас I. Репресивно-каральна система в Україні 1917-1953. Суспільнополітичний та історичний аналіз. У двох книгах. Книга 1. Київ: Либідь - Військо України, 1994. С. 268. 
of laws were directed to work to the western areas. It brought to full lawlessness, arbitrariness which was created in the Carpathian region of OUN $^{7}$. For example, on June 26, 1944 it was appointed thrice convicted citizen, besides two last sentences at the time of appointment were not served to the position of an assistant prosecutor of Chernivtsi region ${ }^{8}$.

Owing to such skillful selection of experts in bodies of prosecutor's office of the western areas the situation of real lawlessness was created. Supervisory authority - the prosecutor's office was not noted by qualitative difference from the bodies of the Ministry of Internal Affairs and MGB. In October, 1946 for the abuse of official position and systematic misappropriation from the arrested citizens the prosecutor of Drohobych region was dismissed ${ }^{9}$. And a chairman of a military court Petrov frankly broke "socialists legality" even against former employees of the Ministry of Internal Affairs, beating out from them evidences (during court sessions they admitted that evidences were received from them through tortures $)^{10}$. The fact that they felt full impunity for the crimes was the serious cause of lawlessness from representatives of the occupational authorities.

During 1945-1946 in Ivano-Frankivsk region 210 facts of "violation of socialist legality" were only officially recorded, however only 8 people were brought to court. The others of episodes were only disciplinary punishments ${ }^{11}$. According to official reports of regional prosecutors of Drohobych region, till June 6, 1945 only 27 cases of violation of "socialist legality", including bodies of People's Commissariat for Internal Affairs (NKVS) - 18 and 8 - bodies of

${ }^{7}$ Сергійчук В. ОУН-УПА в роки війни. Нові документи і матеріали. Київ: Дніпро, 1996. С. 14.

8 Білас I. Репресивно-каральна система в Украӥні 1917-1953. Суспільнополітичний та історико-правовий аналіз. У двох книгах. Книга перша. Київ: Либідь; Військо України, 1994. С. 268.

9 Білас I. Репресивно-каральна система в Украӥні 1917-1953. Суспільнополітичний та історичний аналіз. У двох книгах. Книга 1. Київ: Либідь - Військо України, 1994. С. 268.

${ }^{10}$ ГДА СБУ, ф. 2-Н, оп. 90, спр. 49, арк. 32.

11 Білас I. Репресивно-каральна система в Україні 1917-1953. Суспільнополітичний та історичний аналіз. У двох книгах. Книга 1. Київ: Либідь - Військо України, 1994. С. 268; Український національно-визвольний рух на Прикарпаття в XX cmoлітmі. Документи і матеріали / [відп. ред. проф. Микола Кугутяк]. Том. 2. Книга 2 (1945 - 1946). Івано-Франківськ: КПФ “ЛІК”, 2010. С. 8. 
NKGB were recorded" ${ }^{12}$. From the cases of violation of "socialist legality" from January 1 till July 1, $194540.9 \%$ - the cases of unauthorized executions, $18 \%$ - beating and other crimes against the personality, $22.7 \%$ - misappropriation, 9\% - application of physical methods of influence during the investigation, 9\% - illegal arrests and searches $^{13}$. Most of all, 75\%, "socialist legality" was broken by employees of People's Commissariat for Internal Affairs (NKVS), first of all in Slavsk and Pidbuzh districts, and in the section of NKGB in Turka district ${ }^{14}$. In general, in Drohobych region during January-July, 1945125 violations of "socialist legality" were made ${ }^{15}$. Only in 1946 72 persons were sued at law and administrative liability in 49 cases, from them 22 persons are brought to trial. In 19478 employees were brought to trial for violation of "socialist legality" in 5 cases. Only 2 persons were brought to military court ${ }^{16}$.

In total for the period from liberation to December, 1944 only in Drohobych region 42 employees of NKGB were brought to disciplinary liability (among them 3 abuses of authority, 23 negligent attitudes to work, 12 drunkenness and moral degradation, 2 hooliganisms, 2 other offenses $)^{17}$. However, statistics and ascertaining of the facts gave nothing, violation proceeded. From June, 1944 - till March 15, 1945 72 crimes were committed ( 3 abuses of authority, 35 negligent attitudes to work, 22 drunkenness, 2 hooliganisms, 10 others $)^{18}$.

In the first quarter of 194537 employees of UNKGB and peripheral bodies (14 negligent attitudes to service, 2 violations of socialist legality, 1 manifestation of cowardice, 2 hooliganisms, 10 drunkenness and moral decay, 2 losses of weapon, 6 other offenses) are taken to responsibility by a special inspection of OK UNKGB of Drohobych region. Among them 33 people were sentenced according to administrative area, 4 materials were sent to NKGB USSR for

12 ДАЛО, ф. П-5001, оп. 6, спр. 46, арк. 157 зв.

13 ДАЛО, ф. П-5001, оп. 6, спр. 46, арк. 157 зв.

14 ДАЛО, ф. П-5001, оп. 6, спр. 46, арк. 233.

15 Літопис УПА. Нова серія. - Т. 4. Боротьба проти УПА і начіоналістичного підпілля: інформаційні документи ЦК КП(б)У, обкомів партї, НКВС - МВС, МДБ - КДБ. Книга перша: 1943 - 1945. Київ - Торонто, 2002. С. 473-474.

${ }^{16}$ ГДА СБУ, ф. 2 ББ, оп. 90, спр. 49, арк. 53.

${ }^{17}$ ГДА СБУ, ф. 71, оп. 6, спр. 609, арк. 10.

${ }^{18}$ ГДА СБУ, ф. 71, оп. 6, спр. 608, арк. 28. 
investigation ${ }^{19}$. In the 2nd quarter of 194543 employees of UNKGB and peripheral bodies of NKGB were taken to responsibility in a disciplinary order and 7 people - to criminal liability by a special inspection of OK UNKGB of Drohobych region ${ }^{20}$.

In general, in 1946 it was brought to criminal and administrative liability according to 49 cases 72 people, from them 22 persons were brought to trial. Including: 1 quarter criminal (5 cases concerning 6 employees), administrative (13 cases -19 employees), 2nd quarter criminal (6/7), administrative (7/11), 3rd quarter criminal (5/9), administrative (12/19), 4th quarter (-/-), administrative (1/1). Result: criminal $16 / 22$, administrative $33 / 50^{21}$.

In 1947192 officers, sergeants and staff of boundary departments of UMGB, Regional Office of the Ministry of Internal Affairs and militia were sentenced for commission of war crimes, other crimes 36 persons $^{22}$. To military personnel, sentenced in 1947, military court applied such measures of punishment: sentenced to probation - 9; sent to disciplinary battalions -19 people; sentenced to 3 years -60 people; to 5 years -45 people; to 10 years -32 persons; to 10 years -22 ; to 25 years -5 people. Totally 192 persons $^{23}$. In the 3rd quarter of 1948 224 criminal cases were in work from which 183 cases were given sentences, 9 cases were sent for reinvestigation, submitted on jurisdiction 2 cases and 30 cases remained ${ }^{24}$. For the crimes concerning the violation of so-called "socialist legality" in the 2nd quarter of 1948 it was sentenced 23 persons $^{25}$. In the 3rd quarter of 194814 (93.3\%) military personnel were sentenced to $10-25$ years $^{26}$.

According to the data of the prosecutors of the USSR, in January, 194853 cases of offenses committed by 68 employees of the Ministry of Internal Affairs (MIA), MGB and the military personnel of the troops of MIA and MGB were documented. The crimes committed in January, 1948: 9 in the western areas, 7 - in the eastern, 3 - armed forces.

\footnotetext{
${ }^{19}$ ГДА СБУ, ф. 71, оп. 6, спр. 605, арк. 1 зв. - 2, 15.

${ }^{20}$ ГДА СБУ, ф. 71, оп. 6, спр. 605, арк. 28.

${ }^{21}$ ГДА СБУ, ф. 2-Н, оп. 90. - Сп. 49, арк. 53.

22 ДАЛО, ф. 5001, оп. 9, спр. 62, арк. 26.

23 ДАЛО, ф. 5001, оп. 9, спр. 62, арк. 27.

24 ДАЛО, ф. 5001, оп. 9, спр. 62, арк. 143.

25 ДАЛО, ф. 5001, оп. 9, спр. 62, арк. 150.

26 ДАЛО, ф. 5001, оп. 9, спр. 62, арк. 151.
} 
Totally - 19 or $35 \%{ }^{27}$; the crimes committed in previous months, but were exposed in January, 1948, 13 - in the western regions, 14 - in the eastern, 7 - armed forces. Totally 34 or $64.2 \%$. Totally in the western areas $-22 / 41.5 \%$, in the eastern areas $-21 / 39.7 \%$, armed forces $10 / 18.8 \%$. Totally 53 or $100 \%$. Thus, data testify about a trend in the growth of crimes: in comparison with the previous month (in which there were 51 cases) the total number of crimes increased by 2 , and the number of the crimes in previous months but exposed in January, 1948 increased by 2 cases (in December, 1947 there were 32, in January, 1948 - 34). In total there were exposed crimes in January, 1948: Stanislav region - 8 in MIA, 2 MGB; Drohobych - 2 in MIA, 0 MGB; Total - 16 MIA, 6 MGB. Including, commited in 1948: Stanislav 3 MIA, 0 MGB; Drohobych - 2 MIA, 0 MGB. Total - 9 MIA, 0 MGB. That is most of all violations happened in Stanislav, Ternopil and Rivne, and on structure of MIA ${ }^{28}$. Stanislavs -6 murders and injured; 0 illegal detentions and beatings; 0 rapes, 3 thefts, 0 illegal withdrawal of property; 1 other crimes; respectively Drohobych $-1 / 1 / 0 / 0 / 0 / 0$. Total $8 / 36.4 \%$ murders and injured; $7 / 31.8 \%$ illegal detentions beating; $1 / 4.5 \%$ rape, $3 / 13.7 \%$ theft, $1 / 4.5 \%$ illegal withdrawal of property; $2 / 9.1 \%$ other crimes. Therefore, these data demonstrate that murders, injureds, beatings that made up 15 cases, or $68.2 \%$ remained the most widespread types of offenses. The characteristic sign of these crimes was the fact that from 22 violations ( 23 violators) 11 were carried out by drunk police officers. According to the official status 23 violators were distributed: a deputy chief of regional department - 1 (or 4.3\%), operatives $-9(39.1 \%)$, district police officers -7 (30.5\%), militiamen $6(26.1 \%)$; according to party accessory: members and candidates of Communist Party (bolsheviks) of Ukraine - 10 (or 43.5\%), members of the Union Leninist Young Communist League - 3 (13\%), non-parties -

27 Повоєнна Украӥна: нариси соизіальної історії (друга половина 1940-х середина 1950-х рр.). Колективна монографія / [відп. ред. В. М. Даниленко]. У 2-х книгах, 3-х частинах. Київ: Інститут історії України НАН України, 2010. Ч. 3. C. 187.

28 Повоснна Україна : нариси соичільної історії (друга половина 1940-х середина 1950-х рр.). Колективна монографія / [відп. ред. В. М. Даниленко]. У 2-х книгах, 3-х частинах. Київ: Інститут історії України НАН України, 2010. Ч. 3. C. 188 . 
$10(43.5 \%)^{29}$. Totally in 1946-1947, 1 quarter 1948 - 214 crimes, among them in $1946-17,1947-159,1$ quarter of 1948 - 38. In Drohobych region - 15/0/11/4; Transcarpathia - 4/0/4/0; Stanislav 11/1/6/4; Chernivtsi - 4/0/3/1 ${ }^{30}$.

Violation of socialist legality also further took place as well. So, during 1949 in the western regions of the USSR only according to official data 29 cases of violation of "socialist legality" and other crimes committed by the employees of repressiv- retaliatory bodies and connected with murders of local citizens, in particular, by 7 - employees of MGB, 17 - bodies of militia, 5 - the military personnel of VV MGB took place ${ }^{31}$. Besides, 21 cases of illegal use of weapons of the employees of militia of the USSR in the western areas in the result of which 21 persons were injured ${ }^{32}$.

In general, there was a tendency to reduction of violation of socialist legality in the next years in the Carpathian region. For example, in Ivano-Frankivsk region in 1950 the violation of the Soviet legality decreased by $42 \%$ in comparison with 1949. In 1950 only 116 violations took place, including: a) 16 murders; b) 50 beatings of citizens; c) 14 illegal searches and withdrawals of property; d) 5 illegal detentions of citizens; e) 31 other violations.

Analyzing offenses and violations during the 1st and 2nd quarter of 1952, security officers noted that in general Drohobych region the number of violations and immoral manifestations among staff of militia after the decision of bureau of regional committee of RC (b) did not change. So, if in the 2 nd half-year of the previous year the $103^{\text {rd }}$ immoral manifestations and violations of office discipline of $5.3 \%$ of staff took place, then in the first half of the year $1952-92$ violations, that is $5 \%$ of staff. If in the 4th quarter of 1951 there were 55 immoral manifestations

29 Повоєнна Україна : нариси сочуіальної історії (друга половина 1940-х середина 1950-х рр.). Колективна монографія / [відп. ред. В. М. Даниленко]. У 2-х книгах, 3-х частинах. Київ: Інститут історії України НАН України, 2010. Ч. 3. СC. 189.

30 Повоєнна Украӥна : нариси соияіальної історії (друга половина 1940-х середина 1950-х рр.). Колективна монографія / [відп. ред. В. М. Даниленко]. У 2-х книгах, 3-х частинах. Київ: Інститут історії України НАН України, 2010. Ч. 3. СC. 232.

${ }^{31}$ ГДА СБУ, ф. 13, спр. 372. - Т. 59, арк. 13.

${ }^{32}$ ГДА СБУ, ф. 13, спр. 372. - Т. 59, арк. 13. 
and misconduct $(2.9 \%$ of staff), then in the 1 st quarter -52 (or $2.8 \%$ ) and in the 2nd quarter - 40 (or 2.2\%). By the types of violations: 35 cases of drunkenness (the $1^{\text {st }}$ quarter -28 , the $2^{\text {nd }}$ quarter -7 ), 14 cases of negligent attitude to work (7/7), 10 violations of sentry duty (6/4), 7 violations of the Soviet legality (3/4), 4 suicides and attempts to it (2/2), 2 illegal uses of weapons with injured (1/1), 4 thefts, misappropriation, embezzlement $(3 / 1), 5$ cases of rough and inattentive attitude towards citizens (0/5), 10 - others (1/9). Totally 92 (52/40). As we see some, though insignificant, reduction of number of violations in the second quarter happened mainly due to misdemeanors, but other serious violations on the contrary increased ${ }^{33}$.

Security officers (on May 28, 1945) were forced to recognize that the number of the cases of violation of socialist legality by of the military (WB and GOGP) which were in areas and villages constantly increased, noting that such state of affairs the majority of district solicitors did not notice. Violations of "socialist legality" took impressive scales and somehow to eliminate the shameful phenomenon, it was offered to qualify them as war crimes ${ }^{34}$. However, relatively strict measures did not give the tangible result.

The mutual responsibility, and respectively the fact that special inspections of People's Commissariat for Internal Affairs and NKGB specially delayed with investigation of affairs of employees who committed a crime, impunity was the serious cause of lawlessness from representatives of law enforcement agencies (or not appropriate punishment concerning the committed crime). So, by a special inspection of UNKVD of Drohobych region on April 25, 1945 the investigation on the employee of Slavsk RO People's Commissariat for Internal Affairs Ukhalkin was not completed though the crime was committed by him on December 30, 1944 (in a state of alcohol intoxication, leaving the building of RO People's Commissariat for Internal Affairs, opened chaotic fire and killed a wife of a combatant Borisov, who visited the husband. The chief of RO People's Commissariat for Internal Affairs instead of taking measures in relation

\footnotetext{
33 ГДА СБУ, ф. 71, оп. 6, спр. 295, арк. 11.

${ }^{34}$ ГДА СБУ, ф. 17, оп. 24, спр. 7, арк. 59.
} 
to Ukhalkin, arrested the fighter Borisov and all his property was withdrown and taken illegally by the employees of DD NKVS ${ }^{35}$.

\section{Main directions of the violation of socialist legality}

In total in the problem of violation of socialist legality it is possible to allocate several directions: illegal detention, the use of the forbidden investigation methods, unauthorized executions and murders, robberies, withdrawal and misappropriation, misconduct, beatings, rape, bribery, suicides, firefights between workers of repressive retaliatory system, injury, torture, and so forth.

- illegal detention which, of course, was followed by robbery, beatings. Since January 1 to June 153591 persons were detained by the bodies of MIA in Drohobych region among them only 829 were arrested. The others, 2762 persons, were detained groundlessly ${ }^{36}$. For the purpose of elimination of the specified shortcomings it was offered to send to BB department five experienced investigators from militia. A deputy chief of UNKVD the lieutenant colonel of state security V. V. Vasilyev was expected to find someone to help an BB inspector (a chief - a senior lieutenant of state security Gornin) ${ }^{37}$.

The similar situation took place and in other areas. So, to February 9, 1946 the check in Rakhiv district of Transcarpathia region established the facts of gross violation of revolutionary legality from the party of District committee, bodies of prosecutor's office and court which appeared in illegal massive bringing peasants to criminal liability for non-performance of labor duties. So, national committee, having found no reasons of non-performance by the population of labor duties, transferred the list with 400 peasants to a district prosecutor for criminal prosecution. On the basis of these lists the prosecutor Vashchuk and the

35 Іваненко В., Якунін В. ОУН $і$ УПА у Другій світовій війні: проблеми icmopiozрафії та методології [монографія]. Дніпропетровськ: “АРТ-ПРЕС”, 2006. С. 279; Сергійчук В. ОУН-УПА в роки війни. Нові документи і матеріали. Київ: Дніпро, 1996. С. 300; ДАЛО, ф. 5001, оп. 6, спр. 46, арк. 49.

36 Білас I. Репресивно-каральна система в Україні 1917-1953. Суспільнополітичний та історичний аналіз. У двох книгах. Книга 2. Документи і матеріали. Київ: Либідь - Військо України, 1994. С. 647.

37 Поліковський М. Радянська міліція в боротьбі з українським підпіллям на Дрогобиччині (1944-1950рр.) (мовою документів) // Студї політологічного иентру “Генеза”. 1997. № 1. С. 78. 
national judge Polovaga began mass trials against the peasants. Without any preliminary investigation they were summoned by groups of 1520 people and judged. Many of them at the beginning of the trial did not even know the reasons of the summons. As a result of massive involvement of peasants to judicial responsibility, among them there were even persons who because of old age and other reasons were not subjects to labor duties ${ }^{38}$.

From among the reasons illegal detentions was that the admitistration of special bodies did not check primary data on the basis of the investigation, hasty tried to carry out mass arrests and through tortures to force arrested to undertake a nonexistent fault ${ }^{39}$. The facts of illegal detentions took place during the entire period of the formation and functioning of the Soviet power in the Carpathian region of $\mathrm{OUN}^{40}$.

- the use of forbidden investigation methods. Lack of discipline was one of elements which generated crime. For the increase of the level of discipline all sentences (on crimes by employees of People's Commissariat for Internal Affairs, NKGB, militia and the military personnel of troops of NKVS (People's Commissariat for Internal Affairs)) which were passed by military court, were given the relevant orders and appeared to all staff. The copies of sentences were turned out by military court and chiefs of border troops of the Ukrainian district for their military personnel. However, all attempts to raise discipline did not make success.

In the system of repressive - retaliatory bodies the situation of full lawlessness, total misconduct which indispensable element was continuous beatings, cruel treatment over prisoners was created. And, it was afforded by both ordinary employees, and heads of departments. So, Dmitro Kaminskyi during the investigation gave evidences about the belonging to OUN which then refused. A chief of the $2^{\text {nd }}$ department of UNKGB of Ivano-Frankivsk region the lieutenant colonel of state security Marchenko and a deputy chief of the $2^{\text {nd }}$ department the senior lieutenant of state security Makarov beat him ${ }^{41}$.

${ }^{38}$ ГДА СБУ, ф. 16, оп. 7, спр. 4, т. 3, арк. 249-250.

${ }^{39}$ ГДА СБУ, ф. 2-Н, оп. 54 (1953), спр. 3. - Т. 1, арк. 134.

${ }^{40}$ ГДА СБУ, ф. 71, оп. 6, спр. 603, арк. 9; Спр. 605, арк. 9зв.; ДАЛО, ф. 5001, оп. 6, спр. 46, арк. 51.

${ }^{41}$ ГДА СБУ, ф. 2-Н, оп. 54 (1953), спр. 3, т. 1, арк. 131. 
On May 3, 1945 the issue of violation of so-called "socialist legality" by a chief of Turka RO NKGB I. Dubovyk, a senior operative A. Sergeyev who in the course of investigation applied physical means of influence to detainees was discussed at the meeting of the bureau of Drohobych regional committee of $\mathrm{CP}(\mathrm{b}) \mathrm{U}$. Besides, Dubovyk approved the arrest of six innocent people that were beaten. Dubovyk and Sergeyev received only a reprimand for that. Soon the employees of Turka RO NKGB self-willedally shot 2 persons ${ }^{42}$.

January 7, 1949 to the village Nyzhni Vorota of Volovetsk district arrived the Red Army man of the 311th regiment of troops of MGB Ivan Salkov from the territory of Drohobych region to the soldiers of the 437th post (the same regiment) for the purpose of a friendly match. Being in the village Nyzhni Vorota, drunk I. Salkov on January 7, 1949, approximately at 22:00, came into a village club where at that time the movie for residents of the village was shown, and threw a hand-grenade. As a result of explosion of 12 citizens of the village received injuries ${ }^{43}$.

Special employees of the ministry for the purpose of check of the facts of violation of the Soviet legality (a considerable part of the facts about which the prosecutor wrote were confirmed, separate only partially) did not bring much help, who were in UMGB of the USSR of the western areas specified in the letter of the military prosecutor of troops of the Ministry of Internal Affairs of the Ukrainian district were specially sent (July 6, 1948 No2/004859) ${ }^{44}$.

At the same time, it is necessary to tell that with the spell of time special bodies began to carry on the investigation more carefully. Prosecutors of the military district treated the cases of convicts better, some cases were returned to reinvestigation, and prisons were released. The investigating authorities were demanded thorough proofs of nationalist activity. Possessing this information, nationalists recommended to witnesses not to give investigative any evidences. Noted, at the same time, that judge People's Commissariat for Internal Affairs for violation of socialist legality. These circumstances it was

42 ДАЛО, ф. П-5001, оп. 6, спр. 46, арк. 145-146.

43 ГДА СБУ, ф. 2-Н, оп. 59 (1953), спр. 11, арк. 55-56.

${ }^{44}$ ГДА СБУ, ф. 2-Н, оп. 99 (1953), спр. 8. - Т. 5, арк. 322-323. 
necessary to take into account and after each case to write complaints to prosecutors about thefts, and physical abuse of employees of NKVD ${ }^{45}$.

- unauthorized executions and murders. Unauthorized, groundless executions of captured nationalists suspected of cooperation with liberation movement, even ordinary people were especially shameful phenomenon $^{46}$.

A chief of Storozhinets regional department of NKVC (People's Commissariat for Internal Affairs) of Chernivtsi region issued the order in which he warned insurgents that in they had to leave the forest till October 1, 1944, otherwise the locals would be shot. On October 17 this order was given: on the outskirts of Storozhinets a public execution of three civilians took place in the presence of their children and the family. As a result of these actions the population of Storozhinets began to escape to Romania: from October 17 to October 2016 families ran away $^{47}$.

The similar facts of groundless execution of civilians took place in other districts of Drohobych, Ivano-Frankivsk, Transcarpathia, Chernivtsi regions. It is clear, that such "severity" of the law to workers promoted implementation of crimes.

Also periodic party meetings did not help to fight against violations. Often during the work workers carried out several violations. So, at a regional party meeting of Gorodenko district of Ivano-Frankivsk region (on August 5, 1946) the question of violation by certain members of socialist laws was discussed. The example of a senior militia operative Gerasimenko who during interrogations hit detainees into PTDC. The Party member Savytskyi in a condition of alcoholic intoxication shot an innocent citizen, after that he was arrested and began to carry on the investigation. On protection of himself and subordinates a chief RO MGB told that "violations of the Soviet laws is discrediting of the Soviet power", did not fail to note that in bodies of MGB the majority had all

${ }^{45}$ ГДА СБУ, ф. 13, спр. 398. - Т. 18, арк. 344.

${ }^{46}$ ГДА СБУ, ф. 71, оп. 10, спр. 25, арк. 58.

47 Білас І. Репресивно-каральна система в Україні 1917-1953. Суспільнополітичний та історико-правовий аналіз. У двох книгах. Книга перша. Київ: Либідь; Військо України, 1994. С. 263. 
cases of violations of the Soviet legality at a chief of RO MGB Zakharov $^{48}$.

- robberies. A bigger problem were continuous robberies which captured all areas, and in certain regions became a serious problem which could not solve arrived administration. So, security officers wrote that with arrival and placement of military units of $52^{\text {nd }}$ army and border troops in the territory of Drohobych region there were registered a significant amount of cases when fighters and officers of RA (Red Army), broke the Soviet legality, were engaged in marauding, destroyed houses and even carried on counterrevolutionary propaganda among inhabitants from August to October $20^{49}$. The problem took essential scales and captured all regions, about what, for example, in certain places of dislocation of various divisions the Soviet power even issued special resolutions about marauding and illegal assignment of things, values, weapon by the ordinary and non-commissioned officer's list of 237 and 240 people 19 WB of VV NKVS (Chernivtsi region) ${ }^{50}$.

The group of agents - fighters of Hust district department of MGB of Transcarpathia region Mykhailo Anton, Philipp Anton, Petro Lemko, Vasil' Tegza under the leadership of the agent - fighter Karmelyuk during 1948 on the territory of the district under the guise of OUN committed 13 armed robberies, in some cases having hard beaten the victims. At the same time used weapon, received in Hust district department of $\mathrm{MGB}^{51}$.

A group of militant agents of the Khust district department of the MGB of the Transcarpathian region, consisting of Mikhail Anton, Philip Anton, Petr Lemko, Vasily Tegz, led by the Karmelyuk militant agent in 1948 , carried out 13 robberies on the territory of the OUN under the guise of the OUN. At the same time used weapons obtained in Khust district department of the MGB.

${ }^{48}$ ДАІФО, ф. П-12, оп. 1, спр. 23, арк. 50 зв.

49 ГДА СБУ, ф. 71, оп. 6, спр. 33, арк. 105 зв. - 106; спр. 97, арк. 170-172; спр. 609, арк. 75-76, 79-130; ДАЛО, ф. 5001, оп. - 6, спр. 46, арк. 48, 50, 57, 60, 62, 297-300, 323.

${ }^{50}$ ГДА СБУ, ф. 2-Н, оп. 65, спр. 4, арк. 183.

51 Білас I. Репресивно-каральна система в Україні 1917-1953. Суспільнополітичний та історико-правовий аналіз. У двох книгах. Книга перша. Київ: Либідь; Військо України, 1994. С. 176. 
The problem of robberies took a serious toll and led to the fact that it was reported to the People's Commissar of State Security of the USSR V. M. Merkulov, a People's Commissar of State Security of the $3^{\text {rd }}$ rank Savchenko (from a Deputy Chief of the State Security Service of the USSR, State Security Commissioner Rodionov). On June 5, 1945, he issued a report on the unlawful seizure and use of belongings and valuables arrested by some UNDP personnel in Ivano-Frankivsk region. In order to solve the problem, it was considered necessary to send a special inspector and an officer of the ACHF of the NKDB of the USSR to carefully investigate the facts about the unlawful seizure and appropriation of the arrested persons by the staff of the $\mathrm{UNCD}^{52}$.

The investigation found that the control and accounting of the material assets seized from the detainees was poorly organized. There were isolated cases where the things of the arrested were seized by the judiciary, and individual UNSC staff, being personally interested in learning about the things they need, were seized and taken for personal use. Thus, in the arrested for anti-Soviet agitation G.I. Yazhemska a deputy Chief of the $2^{\text {nd }}$ department of the UNCDB, State Security Major Rybakov seized and transported to his apartment a soft sofa, 6 soft chairs, a wall clock, a rug and a chair. The fisherman brought these things to his apartment with the permission of the former deputy. the head of the UNDB, the lieutenant colonel of state security Pavlenko. The arrested Yazhemska's belongings were also transported to the apartment of a Deputy Chief of the $2^{\text {nd }}$ department of UNDB, Captain of State Security Kachur (a wardrobe, a desk, a wooden sofa, 2 chairs, a mirror). These things Kachur took with the permission of an UNDB chief Colonel Mykhailov ${ }^{53}$. Part of things (a bed, a wardrobe, a table, a sewing machine, a women's suit, etc.) was taken by an operator of UNDP, of the $3^{\text {rd }}$ department, $2^{\text {nd }}$ unit, senior State Security Lieutenant Vereshchak, the Yazhemska's case was on charge. Some of the items seized from detainees were used to equip secret apartments and wardrobes. The lack of proper control and accounting allowed individual employees to engage in the appropriation of tangible assets. UNDP misappropriated 12 receivers, but they were nowhere to be found, there were none in the warehouses, and to whom they were distributed, it is

\footnotetext{
52 ГДА СБУ, ф. 16, оп. 92, спр. 52, арк. 31.

${ }^{53}$ ГДА СБУ, ф. 16, оп. 92, спр. 52, арк. 32.
} 
unknown. Illegal seizure of property had the other side of the coin. In difficult financial conditions, they created an unhealthy atmosphere in the staff ${ }^{54}$.

In 1947, a series of robberies was carried out in Kitsman district of Chernivtsi region by a group of 3 UMDB employees: a son of a member of Chernivtsi Regional Court, Konstantyn Grebnev (born 1918), worked as a delivery manager of "the $1^{\text {st }}$ of May" artillery, a former UMDB warehouse keeper; Volodymyr Pycepa (born 1927, a member of the Supreme Commissar of Commissariat of Internal Affairs, a sailor was on short-term leave), his mother worked as a member of Chernivtsi Regional Court; Mykola Oblogin (born 1925, a member of the Supreme Communist Party of Belarus), a watchman of the UMDB Investigation Department; Efim Tytorovych (born 1923, candidate for the CPSU (b)), a UMDB watchman; Konstantin Filipov (born 1924), a former UMDB radio operator; Stepan Isniuk (born 1915), a UMDB driver; Leonid Sydorov (born 1919), the driver of the artel "May 1"55. The group was organized by K. Grebnev ${ }^{56}$.

In addition, it should be noted that with the second Bolshevik occupation, the number of criminal offenses increases. Analyzing the social composition of the perpetrators, the Chekists noted, among them, the persons who came from the eastern regions for food, criminaltouring element, robbery and murder at the expense of some morally unstable servicemen stationed on the territory ${ }^{57}$.

- shameful behavior. This was not a feature of the regions of the Carpathian region, similar crimes were committed in all western regions of the USSR ${ }^{58}$. The problems arose in the context of periodic conflicts between different military units. Thus, on the territory of Yaremche district, a military group 131 of a railway construction battalion, commanded by Lieutenant Colonel Ustinov, was stationed. During their stay in 1944, the soldiers and individual officers of the said unit violated social law, but the leadership not only prevented it, but also encouraged crimes. Among them: intoxicated fighters broke into public places,

${ }^{54}$ ГДА СБУ, ф. 16, оп. 92, спр. 52, арк. 33-34.

${ }^{55}$ ГДА СБУ, ф. 2-Н, оп. 90 (1951), спр. 33, арк. 105.

${ }^{56}$ ГДА СБУ, ф. 2-Н, оп. 90 (1951), спр. 33, арк. 105 зв.

${ }^{57}$ ГДА СБУ, ф. 2-Н, оп. 90 (1951), спр. 33, арк. 24.

${ }^{58}$ ГДА СБУ, ф. 2-Н, оп. 65 (1953), спр. 4, арк. 123, 131-133, 240. 
threatened weapons with NKVD police officers and soldiers of the 112 Border Command's cross-border commando, and carried out aimless firing while destroying homes, refusing to submit to local authorities ${ }^{59}$.

- beating. In Chornolytskyi district, a deputy district commander Droshdov in the village of Potochyshche illegally seized grain and flour, beat citizens, for which he was prosecuted ${ }^{60}$.

- rape. At the same time with other types of crimes, the Chekists were especially often involved in rape. Real numbers cannot be restored because they were carefully hidden. However, the scale of the problem did not allow to disguise it completely. Moreover, current researchers claim that they often deliberately arrested women for further rape. So, T. Strokach emphasized that among arrested NKVD and NKDB women made up 60\%. OUN documents noted that after the arrest, almost all girls became ill with venereal diseases ${ }^{61}$.

- bribery. It should be noted about another kind of violation of social legitimacy inherent in the Soviet system - bribery, which, incidentally, destroyed the system itself from within. This phenomenon took place throughout the period of its existence and covered all spheres of life. For the first time, we learn about it from the materials of the end of November 1944, according to which the employees of Sambir District Military Commissariat and the conscription commission were engaged in unlawful dismissal from the military service, taking big bribes for it. The Chekists found out that members of the conscription commission, ruled by a head of the $2^{\text {nd }}$ department of RVK Pendurin, were systematically dismissed by the military, and for this they received bribes (both with food and money). Almost all employees were involved in the case: Ivan Pendurin, a Chairman of the Appeal Committee; a head of Sambir district health department and a head of the medical commission at REC, Maria Litvinova, as well as doctors, secretaries and even technical staff. A new commission was set up to review the work of REC, which reviewed persons previously found unfit for service in

${ }^{59}$ ГДА СБУ, ф. 2-Н, оп. 107, спр. 1, арк. 190-190 зв.

60 ДАІФО, ф. 1, оп. 1, спр. 558, арк. 13.

61 Український національно-визвольний рух на Прикарпаття в ХХ столітті. Документи і матеріали / [відп. ред. проф. Микола Кугутяк], том. 2, книга 2 (19451946), Івано-Франківськ: КПФ “ЛІК”, 2010, С. 9. 
the army and ascertained the mass release of the military. Only in one settlement of Biskovychi 35 persons were illegally released from the service, which is $80 \%$ of all those who were subpoenaed ${ }^{62}$. There was a whole scheme in which everyone had their function and role. Some of the employees, mostly technical, were engaged in the processing of recruits, explained the possibility of dismissal and acted as mediators ${ }^{63}$. Similar phenomena for the release of prisoners of war occurred in other district military commissariats.

In the period from 1944 to January 1, 1946, in Drohobych region, 19 persons were prosecuted as bribe-takers who illegally released persons from service ${ }^{64}$.

- suicides, shootings between employees of repressive and punitive system. Impunity, permissiveness resulted in low levels of discipline, constant alcohol abuse, lack of control over violations, and a significant number of suicides. On June 30, 1945, in his office, the NKDB RV committed suicide (shot in the temple), the state security captain Vasyl Andrusenko. The investigation found that NKVD RV staff repeatedly illegally took oats for the horses of the regional department. Moreover, V. Andrusenko personally went to the village Gvozdets, where he misappropriated men's pants and a cloth from which he sewed a mattress. This issue has been repeatedly raised in the $\mathrm{RC}$ of the $\mathrm{CP}(\mathrm{b}) \mathrm{U}^{65}$. In the course of the investigation, it was found that V. Andrusenko was negligent in his duties, he was dissatisfied with his work in the western regions of the USSR, repeatedly showed declining moods and was systematically drunk. Arrived at the UNCCD of Drohobych region in October 1944. On June 31, 1944, by the order of the People's Commissar of the State Security of the USSR, V. Andrusenko was arrested on administrative order for 15 days without carrying out his official duties, after which was directed to the disposal of the UNCCD of Drohobych region by the NKD personnel department. In other words, personnel had not only low professional, but also moral

62 ДАЛО, ф. 5001, оп. 6, спр. 46, арк. 7 - 10; ГДА СБУ, ф. 71, оп.6, спр. 29, арк. 14-15 зв.

${ }^{63}$ ГДА СБУ, ф. 71, оп. 6, спр. 29, арк. 17.

${ }^{64}$ ГДА СБУ, ф. 71, оп. 6, спр. 121, арк. 54 зв.

${ }^{65}$ ГДА СБУ, ф. 71, оп. 6, спр. 606, арк. 22-23; ДАЛО, ф. 5001, оп. 6, спр. 46, арк. 170-171. 
and ethical levels, no administration from the eastern regions of the USSR wanted to send the best workers to the western regions of the USSR. Arriving in the region, V. Andrusenko was first appointed a Senior Operations Officer of the $2^{\text {nd }}$ department of the UNCD, and later a Chief of Strilky district department of the NKGB. During his period of work in Drohobych region, he twice raised the questions before the UNDP personnel department about his departure from the region due to illness. In connection with this, he was referred to the medical commission under the sanctions of the UNKDB of Drohobych region and twice was found fit to work in the NCSD bodies in the western regions of the USSR ${ }^{66}$.

The examination of the state of military discipline at the headquarters of the 3 Rifle Battalion $215 \mathrm{cp} 82 \mathrm{dc}$ VV MGB of the Ukrainian District (stationed in Rozhnyativ, Stanislav region) revealed a number of serious violations of military discipline among the headquarters of the staff. Disclosed facts of violations of the discipline were obtained as a result of conversations with the operational staff and some officers, especially with the operative of the counter-intelligence of the MGB of the Ukrainian District, Lieutenant Hasnutdynov, who promptly served the area ${ }^{67}$. A commander of the $3 \mathrm{rd} 215$ Major Pavlo F. Lysenko (born in 1913, Barane-Pole village of Boguslav district, Kyiv region, member of the CPSU (b) (1941), education of $7 \mathrm{cl}$.) was appointed in August 1946, arrived from the MGB troops stationed in Germany. As a commander of the occupation forces, he systematically drank in Germany, led a lousy lifestyle, and did not engage in personnel, resulting in many immoral manifestations in the battalion. In 1946, Major P. Lysenko was sentenced to 2 years of probation by a military tribunal for his inaction and drunkenness. In connection with this decision the court was seconded to the disposal of the HR Department of the MGB of the Ukrainian District. However, despite the court's decision, he was re-appointed $\mathrm{s}$ battalion commander $^{68}$. After resuming his position as commander of the $3^{\text {rd }} 215 \mathrm{cn}$, Major P. Lysenko continued to drink, committed immoral

${ }^{66}$ ГДА СБУ, ф. 71, оп. 6, спр. 606, арк. 24-25; ДАЛО, ф. 5001, оп. 6, спр. 46, арк. 172-174.

${ }^{67}$ ГДА СБУ, ф. 2-Н, оп. 59 (1953), спр. 6. - Т. 2, арк. 13.

${ }^{68}$ ГДА СБУ, ф. 2-Н, оп. 59 (1953), спр. 6. - Т. 2, арк. 14. 
acts and neglected to perform his duties, in particular, drinking both in public and in the battalion's office, demanding money from his subordinates, borrowed the buffets and tea rooms of Rozhnyativ. At the same time, he maintained intimate relationships with local resident Polina Temna, and on this basis conflicts took place in his own family ${ }^{69}$.

Some even continued their criminal activity even after being dismissed. Thus, in a special report (November 1949) by a secretary of Bogorodchany RK $\mathrm{CP}(\mathrm{b}) \mathrm{U}$ to a secretary of Stanislav Regional Committee of the $\mathrm{CP}(\mathrm{b}) \mathrm{U}$, it was noted that a former chief of RD of MGB Syromyatnikov, who, without the means of subsistence, often dealt with extortio. The need to relocate the offender was stressed as it could adversely affect the work of MGB regional department, which already hadn't a positive image ${ }^{70}$.

Objectively, formal convictions and punishments were rather a forced step to, first, at least somehow persuaded a morally degraded contingent of workers, and secondly, to stop being discredited in the eyes of the population of the entire Soviet administration, who did not yet enjoy the support of the local, moreover, it became hateful (because of aggressive behavior) for all residents of the region.

The Chekists themselves apparently delighted the senior leadership with comparative reports of violations of socialist legality of previous years and noted a decrease in negative phenomena. A Prosecutor General's Office usually reported to the higher authorities only about emergencies, leaving aside cases of allegedly minor violations while, in essence, they were serious. That is, many of the violations were simply not registered, and accordingly no investigation was conducted on them ${ }^{71}$.

\section{CONCLUSIONS}

Thus, the violation of social legality was caused by low moral, educational, professional levels of personnel and material support, constant abuse of alcohol, absence of real punishment for the violations

${ }^{69}$ ГДА СБУ, ф. 2-Н, оп. 59 (1953), спр. 6. - Т. 2, арк. 15-17.

70 Украӥнський національно-визвольний рух на Прикарпаття в ХХ столітті. Документи і матеріали / [відп. ред. проф. Микола Кугутяк], том. 2, книга 3 (1947 1957), Івано-Франківськ: КПФ “ЛІК”, 2011, С. 411.

71 ДАЛО, ф. 5001, оп. 6, спр. 46, арк. 157. 
committed, etc. The magnitude of the situation in the Western Ukrainian region with crimes committed by the representatives of the Soviet administration began to threaten the existence of the system itself. That is why forced punishment was applied to them. Although often these punishments were not commensurate with the crime.

\section{SUMMARY}

In the research on the basis of unknown and little-known documents one of the components of the statement's process of the Soviet administration in the Carpathian region of OUN - violation of socialist legality is traced. Main types of violations are allocated and the attempts to clear the scale of this phenomenon were made. It is proved that the existence of repeated crimes was caused by the lack of punishment, and sometimes the encouragement of the administration in constant violations.

\section{REFERENCES}

1.Білас I. Репресивно-каральна система в Украӥні 1917-1953. Суспільно-політичний та історико-правовий аналіз. У двох книгах. Книга перша. Київ: Либідь; Військо України, 1994. 432 с.

2. Білас I. Репресивно-каральна система в Україні 1917-1953. Суспільно-політичний та історичний аналіз. У двох книгах. Київ: Либідь; Військо України, 1994. Книга друга: Документи та матеріали. $688 \mathrm{c}$.

3. ГДА СБУ, ф. 2-Н, оп. 90 (1951), спр. 33.

4. ГДА СБУ, ф. 2-Н, оп. 90 (1951), спр. 49.

5. ГДА СБУ, ф. 2-Н, оп. 54 (1953), спр. 3, т. 1.

6. ГДА СБУ, ф. 2-Н, оп. 59 (1953), спр. 11.

7. ГДА СБУ, ф. 2-Н, оп. 59 (1953), спр. 6, т. 2.

8. ГДА СБУ, ф. 2-Н, оп. 65 (1953), спр. 4.

9. ГДА СБУ, ф. 2-Н, оп. 99 (1953), спр. 8, т. 5.

10.ГДА СБУ, ф. 2-Н, оп. 107 (1954), спр. 1.

11.ГДА СБУ, ф. 13, спр. 372, т. 59.

12.ГДА СБУ, ф. 13, спр. 398, т. 18.

13.ГДА СБУ, ф. 16, оп. 7, спр. 4, т. 3.

14.ГДА СБУ, ф. 16, оп. 92, спр. 52.

15.ГДА СБУ, ф. 17, оп. 24, спр. 7.

16.ГДА СБУ, ф. 71, оп. 6, спр. 121. 
17. ГДА СБУ, ф. 71, оп. 6, спр. 29.

18. ГДА СБУ, ф. 71, оп. 6, спр. 33.

19. ГДА СБУ, ф. 71, оп. 6, спр. 295.

20.ГДА СБУ, ф. 71, оп. 6, спр. 603.

21.ГДА СБУ, ф. 71, оп. 6, спр. 605.

22. ГДА СБУ, ф. 71, оп. 6, спр. 606.

23. ГДА СБУ, ф. 71, оп. 6, спр. 608.

24. ГДА СБУ, ф. 71, оп. 6, спр. 609.

25.ГДА СБУ, ф. 71, оп. 6, спр. 97.

26. ГДА СБУ, ф. 71, оп. 10, спр. 25.

27. ДАІФО, ф. П-12, оп. 1, спр. 23.

28. ДАІФО, ф. 1, оп. 1, спр. 558.

29. ДАЛО, ф. П-5001, оп. 6, спр. 46.

30. ДАЛО, ф. П-5001, оп. 9, спр. 62.

31.Іваненко В., Якунін В. ОУН і УПА у Другій світовій війні : проблеми історіографіі та методології [монографія]. Дніпропетровськ: “АРТ-ПРЕС”, 2006. 424 с.

32. Кентій А. Нарис боротьби ОУН-УПА в Украӥні (19461956 рр.). Київ: Інститут історії України НАН України, 1999. 111 с.

33.Киричук Ю. Український національний рух 40-50-х років ХХ століття: ідеологія та практика. Львів: Добра справа, 2003. $464 \mathrm{c.}$

34. Літопис Української Повстанської Армії. Нова серія. - Т. 4: Боротьба проти УПА і націоналістичного підпілля: інформаційні документи ЦК КП(б)У, обкомів партії, НКВС-МВС, МДБ-КДБ (1943-1959) / [упоряд. Анатолій Кентій, Володимир Лозицький, Ірина Павленко]. Київ; Торонто: [б.в.], 2002. Кн. 1: 19431945. $596 \mathrm{c}$.

35.Повоєнна Украӥна: нариси соџіальної історї (друга половина 1940-х - середина 1950-х рр.): колективна монографія / [відп. ред. В. М. Даниленко]. У 2-х книгах, 3-х частинах. Київ: Інститут історії України НАН України, 2010. Кн. 1. Ч. 3. 336 с.

36. Поліковський М. Радянська міліція в боротьбі з українським підпіллям на Дрогобиччині (1944 - 1950 рр.) (мовою документів) // Студії політологічного изентру “Генеза”. 1997. № 1. С. 76-80.

37. Русначенко А. Народ збурений : Національно-визвольний рух в Украӥні й національні рухи опору в Білорусї, Литві, Латвї, 
Естонії у 1940 - 50-х роках. Київ: Університетське видавництво “Пульсари", 2002. 519 с.

38. Сергійчук В. ОУН-УПА в роки війни. Нові документи $i$ матеріали. Київ: Дніпро, 1996. 496 с.

39. Сергійчук В. Тавруючи визвольний прапор. Діяльність агентури та спецбоївок НКВС-НКДБ під виглядом ОУН-УПА. Видання друге, доповнене. Київ: ПП Сергійчук M.I., 2006. 184 с.

40.Сергійчук В. Український здвиг: Прикарпаття. 19391955 рр. Київ: Українська Видавнича Спілка, 2005. 840 с.

41. Український національно-визвольний рух на Прикарпаття в XX столітті. Документи $i$ матеріали / [відп. ред. проф. Микола Кугутяк]. Том 2. Книга 2 (1945-1946). Івано-Франківськ: КПФ “ЛІК”, 2010. 696 с.

42. Украӥнський національно-визвольний рух на Прикарпаття в XX столітті. Документи $i$ матеріали / [відп. ред. проф. Микола Кугутяк]. Том 2. Книга 3 (1947-1957). Івано-Франківськ: КПФ “ЛІК”, 2011. 768 с.

\section{Information about the authors: Ilnytskyi V. I.}

Doctor of Historical Sciences, Associate Professor, Head of the Department of History of Ukraine, Drohobych Ivan Franko State Pedagogical University 46, Lesi Ukrainky str., Drohobych, Lviv region, 82100, Ukraine

Haliv M. D.

Candidate of Pedagogic Sciences, Associate Professor, Senior Lecturer at the Department of History of Ukraine, Drohobych Ivan Franko State Pedagogical University 46, Lesi Ukrainky str., Drohobych, Lviv region, 82100, Ukraine 


\section{EVOLUTION OF A HYBRID-INFORMATION WAR IN THE CONTEXT OF AGGRESSIVE POLICY OF THE RUSSIAN FEDERATION IN RESPECT TO UKRAINE}

\section{Sytnyk O. M.}

\section{INTRODUCTION}

The phenomenon of hybrid information warfare is quite new, but at the same time it has certain sources in history. Finally formed in the XX century, it has every reason to actively develop in the XXI century. And one of the most significant manifestations of the hybrid information war in the modern world is its use in the context of the current aggression of the Russian Federation against Ukraine.

An analysis of Russian-Ukrainian relations in the post-Soviet space as a manifestation of permanent hybrid aggression by the Russian Federation requires a comprehensive study of the nature and origins of the Kremlin regime's practice of conducting hybrid information wars. Moreover, the term "Kremlin regime" is understood, first of all, as the newest imperial regime of power in the modern RF, which inherited almost all the worst features from the autocratic and Bolshevik totalitarian system.

\section{The evolution of hybrid information warfare}

At first, the terms "hybrid form", "hybrid" were used in relation to political organizations. That is, it was understood that organizations are not political, responsible for the implementation of precisely political functions.

Now hybrid war is generally understood as military operations that are carried out by combining militaristic, quasi-militaristic, diplomatic, informational, economic and other means with the aim of achieving strategic political goals. The specificity of this combination is that each of the military and non-military methods of conducting a hybrid conflict is used for military purposes and is used as a weapon. In the modern world, hybrid conflicts and hybrid threats are usually regarded as some sign of a systemic crisis. At the same time, military and analytical circles lack unity in understanding the phenomenon of 
hybrid warfare. The main question is whether the nature of modern warfare has changed, and are there hybrid methods of warfare with fundamentally new forms of military conflicts, present and future? ${ }^{1}$. This became especially relevant with the onset of the hybrid information war unleashed by the Kremlin regime against Ukraine.

It is difficult to determine when the first hybrid war occurred, and in general, whether a similar fact existed before in history. It is clear that now this phenomenon is becoming more common.

It is important to note that the elements of hybrid warfare have been inherent in the usual aggressive practices of the Moscow state since the sixteenth century.

Now the concept of "hybrid war" is characterized by a combination of classical war with elements of terrorism, partisan and cyber warfare, that is, completely different components. In particular, there is an example of Hezbollah's activities carried out during the Lebanon war and other regional conflicts. She did not actively participate in the war, but used rebels, partisans, and so on.

If you look into the distant past, you can find many historical examples that describe such phenomena, for example, the so-called "Scythian war". Therefore, do not attribute the phenomenon of hybrid warfare to the category of fundamentally new in nature, nature and manifestations. However, its current interpretation is significantly different from the previous one ${ }^{2}$.

At the beginning of the XIVth century, the Castilian prince, commander and writer, Juan Manuel first used the term "cold" and "hot" war. Talking about the long struggle between Christians and Muslims on the Iberian Peninsula, he noted that the "cold" from the "hot" war differs in how they end. "Hot" wars end either in death or in peace, while "cold" wars neither peace nor honor to the one who started them ${ }^{3}$.

1 Світова гібридна війна: украӥнський фронт: монографія. Ред. В. П. Горбулін. К.: НІСД, 2017. С. 19, 20.

2 Що таке гібридна війна? Концепція і тактика гібридної війни. URL: http://faqukr.ru/novini-ta-suspilstvo/145715-shho-take-gibridna-vijna-koncepcija-itaktika.html

${ }^{3}$ Гісем О. В. Всесвітня історія $X X$ cm. Довідник. Кам'янець-Подільський: Абетка, 2003. С. 595. 
As you know, the military strategy includes the following types of wars: small wars, conventional war, regional war. But all these types of touch events when the armed forces of one party are opposed by the armed forces of the other side. In such wars, are used biological, nuclear, chemical, and others who are not the traditional types of weapons, but as a rule, in the classical military engagements, use standard weapons as in the West, "lethal weapons", which, primarily, designed to destroy military forces. There is also the term "symmetrical war", the phenomenon that is the war of the armed forces who are aggressive with different potential opponents, who then become real. A clear example is Afghan war waged by the Soviet Union. So, considering the notion of hybrid warfare, it should be emphasized that this kind of war, uniting a vast range of effects produced by opponent with the use of both military and irregulars involving civilian components. In the writings of military experts, there is close to the term "war of controlled chaos". The term "hybrid threats" has become widespread today, which defines the threats that come from an adversary capable of using traditional and nontraditional tools of hybrid aggression at the same time ${ }^{4}$.

In a certain way, hybrid warfare mean a confrontation arising from technological development, technical growth level defensive tools, offensive weapons, in other words, technologies of warfare. At the same time, significantly changing the objects themselves destruction. They represent not merely the destruction of manpower and destruction of material values. Here the most important weapons are: the influence on the mass consciousness of society, the expert opinions of the persons responsible for making important government decisions, including Ministers, deputies, presidents, when there is a suggestion of certain ideas, the inculcation of values and positions, motivating to perform certain actions. Among other things, hybrid warfare involves a certain armed confrontation. Thus, in addition to

4 Ситник О. М. Гібридний характер російсько-української війни 20142017 років та пошук ефективних засобів протидії. Війна на Донбасі. 20142016 рр.: зб. наук. пращь за матеріалами Другої Всеукраӥнськоӥ наукової військово-історичної конференції «Війна на донбасі. 2014-2016 рр.» (м. Київ, 20 квітня 2017 р.). К.: Національний військово-історичний музей України, 2017. C. 136 . 
traditional weapons, are also used special technology, information, technical and global network device. The concept of hybrid warfare does not reject traditional views on the war, but rather supplements them taking into account dynamic changes in the international security and other relevant factors that affect the methods of warfare. Military analyst F. Hoffman, theorist of the concept of hybrid warfare, which coined the term in a broad appeal came in fact from the thesis of the presence of heredity in the wars of all time, the relevance of historical lessons and methods of warfare and the behavior of enemies, described by Thucydides. At the same time, Hoffman tried to formulate a fundamentally new generalized characteristics of modern conflicts. Central to his conception is the thesis of the strengthening trend of convergence in modern conflicts, which manifested in the rapprochement and interpenetration (conjunction) aspects of war that are usually separate: the physical and psychological dimensions, kineticheskogo and akineticakih weapons, exhibitors and fighting. Convergence covers, in his opinion, regular military forces and proxy groups, it blurs the line between state and non-state actors in the fighting, as well as their unequal armed potentials. This trend is changing shape (modality) of warfare, and the traditional categorical distinction between terrorism and conventional military operations, crime, irregular wars are losing, according to Hoffmann, are of practical importance. Thus, despite the arguments against the term "hybrid war" is impossible to deny that the modern forms of warfare give rise to a significant number of new military, legal, social, moral and other problems requiring urgent solutions. In this context it is considered appropriate to interpret the name "hybrid warfare" as a socalled umbrella term (umbrella term) that covers various aspects of this phenomenon and makes possible the integration and relatively holistic understanding of the wide range associated with diverse and divergent approaches. An umbrella term is, by definition, does not offer a single consistent theory or complementary concepts for all occasions maintaining hybrid fighting. His role is to find common characteristics of hybrid war or the principles of variation sets her signs and also prevent unwanted dispersal of existing approaches and stimulate the search for theoretically sound and effective practical solutions. Another advantage of interpreting hybrid warfare as an umbrella term is to remove the contradiction that arises when using 
the terms hybrid warfare, hybrid warfare, hybrid threats, hybrid adversaries as contextual synonyms in modern expert studies, doctrinal documents, etc. The basis for synonymization is a sign of the hybridity (confusion, complex combination) of conventional, nonconventional and non-military methods: either in the role of threats, or in the conduct of real hostilities, or as a sign of a potential or real attacker (hybrid adversary). Thus, certain logical and substantive inconsistencies in the concept of hybrid warfare are not an argument in favor of rejecting the term and denying the meaning of its application. This is evidenced by the analysis of the conceptualization of ideas about the nature of modern military conflicts on the basis of a description of a set of new terms that arise in the context of technological and political changes and reflect the directions of existing theoretical research.

Hybrid Wars is a XXIst century phenomenon. But in the history of Russian-Ukrainian relations, their individual methods have been used before. In 1917-1921, many of these techniques were already used by Bolshevik Russia in the struggle against Ukraine. This was the response of the former imperial metropolis to the attempt of Ukrainians to defend their independence, proclaimed in January 1918 by the Central Council.Ukraine did not want the Bolshevik dictatorship, the destruction of democratic freedoms, the "Red Terror" and the return to the control of Russia, now Bolshevik. In response, Ukraine sent regular troops from Russia under the red flag of the communist revolution and the fake slogan "helping the fraternal people in the struggle against the world bourgeoisie". The local "fifth column" of the Bolsheviks and other pro-Russian elements, which were especially active in the southern and eastern regions of Ukraine, helped them in every possible way ${ }^{5}$. The treacherous tactics of the Bolshevik Russia against its neighbors to fine-noticed K. G. E. Mannerheim served in the Russian army for a long time, having moved from cornet to the General. In his memoirs, this military leader noted that the official sources lot of trouble over that war the Finns have turned into mere civil war. For such inventions is the desire to blame the legitimate government and the army of Finland

5 Турченко Ф. Турченко Г. Проект «Новоросія» $i$ новітня російськоукраїнська війна. К.: Інститут історії України НАН України, 2015. С. 146. 
in the war, but it will not hide the fact that in 1918 the Finns defended the independence of their state. If they hadn't rose to fight, Finland at best, would become the Autonomous oblast of the Soviet Union, without any national freedoms, without real statehood, and they have no place among the free Nations ${ }^{6}$.

In the spring of 1920 the government of Finland allowed the Communists to hold an organizational meeting of the socialist workers party of Finland. Although the secret police, based on irrefutable evidence, demanded to ban the party and to bring its leaders to trial for treasonous activities, but the government did not react. The Communists got the opportunity openly to pursue its organizational activities, to promote and participate in the parliamentary elections of 1922. As a result, the Communists won 22 seats and was able to defend in Parliament his interests, as well as the interests of Moscow.

June 14, 1939 he was shot down during a regular flight from Tallinn to Helsinki, the Finnish passenger plane "Kaleva". It has been proven that "Kaleva" shot down two Russian fighter, and the Soviet submarine EN route to the area, took possession of all the cargo that was in the plane. Except for the Finnish crew were killed and the passengers; they were foreign nationals, and one of them was flying a French diplomatic courier, the bag of mail which was also trophy. This was confirmed in a few years, officer of the submarine who were captured. 27 November 1939, Molotov informed the Finnish Ambassador that the Soviet government no longer considers itself bound by the Treaty of non-aggression. On the Finnish proposal for the joint investigation of incident with shots of unknown origin in the village of Maynila no attention is paid and distorting the facts, began to argue that the Finnish government was asked to withdraw Russian troops 25 kilometers from the border. In a note dated 29 November 1939, Molotov accused the Finnish armed forces that "they continue to conduct military operations not only on the Karelian isthmus, but also in other areas". December 1, 1939, on the second day of the Soviet-Finnish war, the Soviet information Bureau announced that the

6 Высказывания маршала Маннергейма, которые как бы обращены к Украине. URL: http://from-ua.com/news/405413-viskazivaniya-marshala-manner geima-kotorie-kak-bi-obrascheni-k-ukraine.html 
"city" of Terijoki, and in fact, in a holiday village located near the border of the formed "people's government of the democratic Republic of Finland". The Prime Minister was elected a Finnish Communist, member of the Secretariat of the Comintern O. V. Kuusinen. The next day in the announcement, the Soviet government stated that the appeal for "assistance" made on behalf of the "people's government". At the same time, it was reported that "the people of the Soviet Karelia now reunited with their Finnish counterparts for the tribe to create a single national state". The Soviet media carried out harsh propaganda against the Finnish government, which was especially aimed at the alleged unrest in this country. At the same time, there was a link to "wonderful living conditions" in Estonia. "Finnish-Soviet society for peace and friendship" did everything possible to prepare the ideological information base in Finland and is actively supported by the Soviet Embassy in Helsinki. Greatly increased the number of employees of embassies and consulates, many of them owned by the Finnish language and actively toured the country, showing a special interest in restricted areas ${ }^{7}$. All of the tools and methods of the Soviet Union, testified not only about the prerequisites of a hybrid war, but also of its actual implementation in the real life and political practice.

\section{Modern manifestations of the hybrid information war in the context of the aggressive policy of the Kremlin regime of the Russian Federation}

Now Putin's actions in relation to Ukraine are very similar to the hybrid practice that the Soviet Union used in relation to Finland in the 1930s and 1940s. Not for nothing that in his memoirs Marshal K. G. E. Mannerheim called the Soviet Union Russia. Therefore, the lines from his memoirs are ideal for our time ${ }^{8}$.

Very similar was Moscow's actions in the Balkan region during the last more than hundred years. The Croatian President Grabar-

7 Высказывания маршала Маннергейма, которые как бы обращены к Украине. URL: http://froma.com/news/405413-viskazivaniya-marshala-mannergei ma-kotorie-kak-bi-obrascheni-k-ukraine.html

8 Маннергейм К. Г. Э. Мемуары; Сайт «Военная литература». URL: http://militera.lib.ru/memo/other/mannerheim/index.html 
Kitarovic believes that the Kremlin is involved in a hybrid war in Bosnia and Herzegovina. She said this local newspaper Vecernji List. "Bosnia and Herzegovina still we can't call a stable government, and it still is politically an independent state. The referendum, which was held recently in the Republic of Srpska (part of Bosnia and Herzegovina) was only the first step in a series of possible so-called "referendum", it can lead to the proclamation of independence of Republika Srpska", she said. According to Grabar-Kitarovic, a military confrontation in the Balkans cannot be excluded, because the Russian Federation wants to have power over the events that occur in the region. "We may have a situation in which Russia will begin to bring arms, will conduct intelligence operations and to conduct propaganda in the region", - said the President. It also says that the soldiers of Croatia participate in the NATO action to deter Moscow from provocations. Also Grabar-Kitarovic said that Putin has created such a terrible atmosphere, not all of it can exist. All we need to prove to Russia that we are not so much against it, but primarily want to protect member States of the Alliance - said the President of Croatia ${ }^{9}$. So the modern actions of the Russian Federation in the implementation of manifestations of hybrid war has many analogies in the past.

The resonant world events of recent years, in particular the revolutionary changes in power and armed conflicts in the countries of North Africa, the Middle East and the former USSR, indicate the emergence of new forms and methods that the leading states resort to, trying to achieve their foreign policy goals and solve interstate disagreements. Classical military aggression, when the armed forces are used, is replaced by the so-called hybrid wars. They are of a hidden nature and are observed mainly in the political, economic, informational and other specific areas. Military units are used in small numbers to solve individual tasks. The essence of this approach is to shift the focus of the physical destruction of the enemy in a large-scale war to the use of "soft power" against the enemy country in order to

9 «РФ прагне створення «народної республіки» на Балканах»: президент Хорватії занепокоїлася активністю Росії у Боснії. URL: http://patrioty.org.ua/ politic/rf-prahne-stvorennia-narodnoi-respubliky-na-balkanakh-prezydent-khorvatiizanepokoilasia-aktyvnistiu-rosii-u-bosnii-144812.html 
disintegrate and change its leadership, including this state in its sphere of influence.

Characteristic features of hybrid wars are:

- aggression without an official declaration of war;

- concealment by the aggressor country of its participation in the conflict;

- widespread use of irregular armed groups (including under the guise of civilians);

- Neglect by the aggressor of international standards of warfare, existing agreements and agreements reached;

- mutual measures of political and economic pressure (with formal preservation of relations between the two countries);

- widespread propaganda and counter-propaganda using dirty information technologies;

- confrontation in cyber space ${ }^{10}$.

There are many well-established ideas about the types of wars. To a large extent, they are representations of the general construct of war as an antagonistic destructive clash of the parties, followed by concretization and reduction to a certain method, regime, form of warfare, which are mainly used as characteristic features of types of wars. New military theories, as a rule, arise along with the emergence of new military phenomena that require the development of the art of warfare in new conditions with new tools. In general, typological theories of war, with some exceptions, are abstract constructs. They are usually based on strategic projections of the future, given that a certain method of warfare becomes, or will become further, universal ${ }^{11}$.

Now for Ukraine the question of developing and putting into practice defense means and protection against hybrid aggression is a key one. The most developed in modern military science is the theory

${ }^{10}$ Стратегія і тактика гібридних війн в контексті військової агресії Росії проти України. Незалежний аналітичний центр геополітичних досліджень Борисфен Інтел. URL: http://bintel.com.ua/uk/article/gibrid-war/

${ }^{11}$ Renz B. Russia and hybrid warfare - going beyond the label. Project «Russia and Hybrid Warfare: definitions, capabilities, scope and possible responses». Funded by the Finnish Prime Minister's Office, government's analysis, assessments and research activities. January 2016. P. 2-4. URL: http://www.helsinki.fi/aleksanteri/ english/publications/presentations/papers/ap_1_2016.pdfhttp://www.helsinki 
of conventional or conventional warfare. It can be described as a war using conventional weapons and conventional methods, which is carried out by warring states using regular troops. Such a war consists of operations, which, in turn, include battles and battles of an offensive or defensive nature. In the framework of the theory of ordinary wars in the 1980s, an idea began to form about their stages (generations). The first stage of wars is associated with the massive use of smooth-bore weapons in static, non-maneuverable battles, the apotheosis of which was the Napoleonic wars. The second stage is associated with the appearance of rifled weapons and the possibility of strategic troop deployment by rail. The use of weapons and human power remained massive. An example is the First World War. The third stage is associated with the appearance of heavy armored vehicles, which allowed for deep tactical and operational maneuvers, sometimes leading to victory in a lightning war (Blitzkrieg). And here a striking example is the Second World War. According to the theory of generations of wars, the first two stages are linear wars, since in them the struggle is through a direct clash of battle formations, or lines. From the third generation we can talk about non-linear war, in which the advantage is achieved by a set of maneuver, tactical and operational skill in using military tools. In this sense, all modern wars are non-linear. Fourth generation wars, military theorists, represented to some extent a futuristic phenomenon, in which breakthrough technical innovations, such as highly effective directional weapons (lasers, electromagnetic guns and the like), remotely controlled devices and operations, computerized communication, information and observations. Technology was supposed to radically change the forms and methods of warfare. In pure form, examples of such wars still do not exist. However, under the general "heading" of the name of the fourth generation wars, a whole series of more applied theories eventually emerged, in particular a hybrid war. Concept networkcentric warfare is purely American. It is associated with the so-called revolution in military affairs (Revolution in Military Affairs, RMA) after the US operation in the Persian Gulf in 1991. Idea networkcentric warfare It is to achieve maximum adaptability of troops, thanks to the almost total use of information technology, which is distributed to the level of individual combat units. In such a war, individual units are capable of acting autonomously and 
simultaneously, in a unified system, to achieve the common goal of victory $^{12}$.

One of the causes of the Cold War was the global struggle for the resources of two systems with different types of regulation of industrial relations. It was here that in the warring states there were common features, since the different systems of the USA and the USSR were built on the principles of an industrial society, demanded industrial growth, and hence an increase in resource consumption. Already in 2012, Yu. G. Badakh expressed concern about the actions of the Russian leadership in international relations, their interference in the internal affairs of other states, including Ukraine, which could lead to a new Cold War. Even then, it became clear that the engine of the future war was not ideology, but civilizational incompatibility of different parts of humanity. Since the Russians, especially the older and middle generation, have such a mentality that is constantly looking for the enemy against whom it is necessary to fight. The population of Russia is 140 million people, but the country has one of the largest armies in the world. In Russia, they began to create a new fifth empire, growing for trade in raw materials (mainly oil and gas). She has already begun the rearmament of her armed forces, completed the formation of a global satellite-based guidance system for highprecision weapons for the Kh-555 strategic cruise missiles, deployed Iskander mobile missile systems, and military bases abroad, made attempts to form a powerful continental bloc of states that could challenge NATO, drawing China and India there. In 2009, having the Tashkent agreement, Russia created a military-political alliance with seven former republics of the USSR. She opposes European missile defense and is going to modernize her armed forces, spending on it such sums of money that are close to those spent during the Cold War $^{13}$. Therefore, caution was expressed that Ukraine already then you would have to be especially vigilant and remember the "cold

12 Світова гібридна війна: украӥнський фронт: монографія. Ред. В. П. Горбулін. К.: НІСД, 2017. С. 23, 24.

13 Бадах Ю. Г. «Холодна війна». загальний огляд (1946-1991 рр.): [Електронний ресурс]. «Холодна війна»: історія та уроки. 1946-1991 рр.».: матеріали Міжнародної наукової військово-історичної конференції, 4-5 жовтня 2012 року, м. Севастополь. URL: http://nvimu.com.ua/wp-content/uploads/Pages.pdf 
war", extract lessons from it. Since the latter Stahl rise to new hybrid forms of warfare.

In General, a typical hybrid warfare consists of three main phases: preparatory, active and final. The first stage is preparatory. In the preparatory phase (which can last for several years) the leadership of the aggressor country, with the active involvement of the security services, measures for the formation of ideological, political and military prerequisites for future aggression. These activities include:

- strengthening of the system of state power in the country, including increasing control over all spheres of its activity;

- indoctrination of its own population for the sake of unification around the ideas of nationalism, great-power chauvinism, defense of the so-called "national values and interests", fighting "external enemy" in a "besieged fortress" and the like, as well as the maximum weakening of the opposition in all its manifestations;

- capture information space of an enemy country and use it to their advantage to develop the appropriate mood;

- the destruction of state power of the country-object of aggression, including: bribery of influential officials, politicians and the security agencies; promotion of agents of influence to positions in state government; fomenting confrontation between different political forces and establish control over them (primarily, the number of ideologically close and corrupt political parties and movements);

- a split among the population of an enemy country by stimulating the internal contradictions of the political, ethnic and religious nature (in particular, through the creation and support of various parties, movements and relevant organizations, including extremist);

- the all - round weakening of the country-object of aggression, undermining public confidence in the authorities and also the spread of protest and separatist sentiments in the society as a method of provoking socio-economic and other problems (including through the use of elements of economic trade and energy wars);

- to discredit the foreign and domestic policy of the country of the enemy, imposing its leadership and population of certain ideas and civilizational values by conducting an active information campaign with the use of special methods of "bombing" companies with 
extensive involvement of both state and non-governmental organizations.

The second stage is active. In an active phase (usually lasts up to a year) is hidden aggression against a chosen country, with the purpose of achievement of the objectives.To do this, the following steps are provided:

- In the country-object of aggression, illegal armed groups are created from representatives of local anti-government forces, special services, mercenaries and militants are involved in them;

- an internal conflict is provoked in the country on a political, socio-economic, confessional and interethnic basis, as well as the processes of its development into mass protests of the population, actions of public disobedience, riots and clashes of demonstrators with law enforcement agencies are stimulated;

- Leaders of protest rallies are appointed from among the representatives of opposition political forces at the national or local levels, and they also create alternative "authorities";

- protesters seize (including with the participation of illegal armed groups and special services of the aggressor country) government buildings and important objects of transport and industrial infrastructure, as well as block the activities of law enforcement agencies (including the use of civilians as human shields);

- regular armed forces of the aggressor are introduced into the territory of the country of aggression under the guise of local armed groups ("self-defense units", "militias" and the like) in order to help the opposition and separatists seize power in the state or in its individual regions. In this case, hidden participation of the regular armed forces of the aggressor country in hostilities on the side of the opponents of the current government of the target country of aggression is possible;

- large-scale information campaigns are conducted to support antistate forces in the country-object of aggression, as well as to discredit the actions of his leadership to ensure the constitutional order in the state.

Stage Three - The Final. At the final stage (duration is limited), the aggressor carries out the following work to consolidate its position in the country-object of aggression: 
- full support is provided for the new (formerly opposition) power in the country-object of aggression or the separatist regimes in its individual regions (including the creation of government bodies and power structures of separatists)

- assistance is provided in conducting "referenda" on the orientation of the external and internal course of the target country of aggression, the status of its regions, etc., as well as in conducting "elections" of central and local (including separatist) authorities;

- Self-proclaimed state formations in the country-object of aggression are legalized, the processes of resolving the situation on its territory are being dragged out under the guise of mediation in peace negotiations. At the same time, the aggressor country does not in any way recognize itself as a party to the conflict;

- conditions are created to ensure the military presence of the aggressor in the target country of aggression on a long-term permanent basis (in the form of "peacekeeping forces" or armed separatist formations), as well as for the realization of other, including economic, interests ${ }^{14}$. Almost all of these stages took place during the preparation by the Russian Federation of its aggression against the sovereign state of Ukraine. Particularly long, active and purposeful were measures aimed at: ideological treatment of the population of the Russian Federation to direct its consciousness into the mainstream of the ideas of nationalism, great-power chauvinism, protection of the socalled "national values and interests", the fight against the "external enemy", etc.; the actual occupation of the information space of Ukraine and its use in their own interests for the formation of proRussian sentiments; the destruction of the state power of Ukraine, including blackmail and bribery of influential officials, political figures and the leadership of power structures, the promotion of their own agents of influence on positions in state authorities, incitement of confrontation between various political forces and the establishment of control over them; introducing a split among the population of Ukraine by stimulating internal contradictions of a political,

14 Стратегія і тактика гібридних війн в контексті військової агресії Росії проти України. Незалежний аналітичний центр геополітичних досліджень Борисфен Інтел. URL: http://bintel.com.ua/uk/article/gibrid-war/ 
interethnic and interreligious nature; comprehensive weakening of Ukraine's aggression, undermining the confidence of its population in their own power, as well as the spread of protest and separatist sentiments in society by provoking socio-economic and other problems, with particular emphasis on the Russian Federation on the artificial provocation of trade, economic and energy wars; discrediting Ukraine's foreign and domestic policy, imposing certain ideas and civilizational values on its leadership and population through an active information campaign using special "zombie" methods of the society with wide involvement of the whole spectrum of various organizations aimed primarily at spreading the ideology of the "Russian world".

It is believed that war is not so much a battle on the battlefield, war is a battle for the minds, for the idea. Moreover, the concepts of "coercion" and "violence" are distinguished. Indeed, armed victory is often a Pyrrhic victory, because it is associated with violence. Violence can change the boundaries (borders) of a part of civilization, violence can force a particular society to follow certain rules of behavior, cause temporary emotional states - horror, fear, fear, but all this is nothing more than an effect on the external manifestations of this society. By the force of influence on the psyche, violence can never be compared with coercion, that is, with that inner state that every psyche accepts consciously, which goes back to the subconscious and forms the value orientation of the individual psyche and entire generations of a particular society. It is here - in influencing individual worldview paradigms (psychological attitudes) and personal sensory-emotional states, that hides the real key to victory over a victim society. Influence on the psyche is tantamount to an influence on parts of the civilizational community, therefore, the deeper and longer this influence, the more stable the new worldview stereotypes and attitudes laid down by propaganda. The power of the information war and its technologies lies in the emphasis on the psyche, on worldviews and value orientations of different generations. The information war provides bloodless decays and unions of individual civilization communities. The manipulation of the sensory and emotional state of the psyche and consciousness is the most effective means of war, which does not lead to temporary changes in the boundaries of individual civilization communities, but in more stable and deep dimensions. In particular, the result is the emergence 
of a significant group of society, whose representatives are distinguished by a deformed consciousness and psyche, dependent on external information carriers, as a rule - the country of the aggressor.

In addition to reasons of an objective nature (a change in the economic and political realities of the country), subjective reasons also influence the perception of events - primarily those related to the hybrid nature of the war. The hybridity factor provides for a large role of information impacts on the population, which are conducted at all levels of communication, affecting all varieties of worldview. In such a situation, there is a segmentation of public consciousness - the only and consistent picture that would rely on the historical images of the war known to the population ("World War II", "Afghanistan") did not take shape in the mass consciousness. The perception of the war remains extremely mixed - despite significant efforts by state propaganda, the adoption of laws and the activities of civil society activists $^{15}$.

The peculiarity of the Afghan war (1979-1989) consists primarily in the fact that a huge mass of the population participated in it, which had never before held weapons in their hands. Recruitment into the ranks of dushmans was led by a wide agent network throughout the country. The advantage of the Mujahideen was the lack of a certain center in them. Throughout the entire armed conflict, it was a combination of many diverse groups. The field commanders led them, but there was no "leader" among them. Many Soviet raids were nullified by the effective propaganda work of the enemy among the local population. For the Afghan majority (especially in deep provinces with a patriarchal order), Soviet troops have always been invaders. Simple Afghans did not feel any sympathy for socialist ideology. Even at the beginning of this war, during the liquidation of Amin, the Soviet special forces used precisely hybrid methods. ${ }^{16}$.

As A. Blotsky noted, special cynicism lies in the fact that all wars, especially at the present time, are decided by people who are absolutely confident in their security and impunity. They never risk

15 Там само. С. 50, 275, 320

16 Що таке гібридна війна? Концепція і тактика гібридної війни. URL: http://faqukr.ru/novini-ta-suspilstvo/145715-shho-take-gibridna-vijna-koncepcija-itaktika.html 
anything. Neither in Afghanistan, nor in any hot spot of the former USSR, have any of them died. None of them were jailed for resolved insanity. If before - three hundred, five hundred, a thousand years the leaders of the states personally led their subjects to attack, risking the same as an ordinary fighter, then over the past two hundred years, leaders and inspirers of wars have preferred to sit more and more reliably behind the backs, hiding behind the backs of their vassals. Another thing is ordinary soldiers. They, like a thousand years ago, are familiar at the forefront. Once there, they immediately realize that they can be killed. If someone nearby dies, then the feeling of danger develops into a steady desire to be saved at all costs. And even later, a completely fair and logical idea comes that here, in war, this can be done in only one way: to shoot, shoot and shoot again ${ }^{17}$.

One of the indicators of hybrid warfare in Ukraine is the use of asymmetric military operations, which are characterized by a significant difference in military force and the strategies and tactics of the participating countries. From the point of view of international law, such a strategy is that Ukraine has no formal reason to fight the aggressor country, which unofficially supports militants and terrorists. When creating the so-called New Russia and resolving the armed conflict in eastern Ukraine, the following were observed: destabilization of the eastern and southern regions of Ukraine through the organization of massive anti-government protests, clashes with law enforcement agencies and supporters of Ukraine's unity, as well as the seizure of administrative buildings; the implementation of the "Crimean" scenario in the Donetsk and Lugansk regions, including the establishment of control over part of their territories, the creation of "militia groups" from among representatives of Russian special services, criminalized law enforcement agencies and local pro-Russian forces; "Legalization" of the so-called Donetsk and Lugansk People's Republics (DPR and LPR) by holding appropriate "referenda as well as elections" of their "authorities"; providing Russia with comprehensive support to the separatists, including financing their activities, training militants and supplying them with weapons, military equipment and ammunition, as well as the introduction of

17 Блоцкий О. Психология войны. URL: http://samlib.ru/b/blockij_o_m/ psihologijawojny.shtml 
Russian troops into the territory of the DPR and LPR; the implementation by the Russian Federation of political and economic pressure on Ukraine, as well as the buildup of the armed forces of the Russian Federation near the Ukrainian border; discrediting Ukraine's military operation against Russian-terrorist groups and the country's disintegration, attempts to present this operation as "punitive against its own population"18.

Modern Kremlin imperialism did not arise immediately - it took decades to formulate, and no serious attempt was made to stop this formation. Moreover, the Russian Federation was considered by the leading states of the world not as a potential threat to peace and security, but as a quite adequate member of the world community or even as one of its leaders. And so the "reset" of Kremlin imperialism took place. It was the Russian Federation that over the years has been observing interethnic conflicts and manifestations of regional imperialism in the Balkans, conducting protracted and ineffective negotiations, having never found a balanced and generally acceptable solution to the next Balkan crisis, leaving the possibility of its further exacerbation historically open. The Balkans under the influence of external provocation can again ignite. This will close the antagonistic arc in the southeast of the Euro-Atlantic community and make it extremely difficult to comply with international law. Also, it was the Russian Federation that plunged the Middle East into chaos, destroying not so much autocratic dictatorial regimes as the statehood of the Middle Eastern peoples. Thus, instead of democratization, the Euro-Atlantic community received general destabilization in the region, an outbreak of militant fundamentalism and international terrorism, refugee flows and a number of humanitarian disasters, and the Russian Federation was another geopolitical "training ground" for implementing its destructive foreign policy ${ }^{19}$.

18 Ситник О. М. Гібридний характер російсько-української війни 20142017 років та пошук ефективних засобів протидії. Війна на Донбасі. 20142016 рр.: зб. наук. праць за матеріалами Другої Всеукраӥнської наукової військово-історичної конференції «Війна на донбасі. 2014-2016 рр.» (м. Київ, 20 квітня 2017 р.). К.: Національний військово-історичний музей України, 2017. C. 140 .

19 Власюк О.С. Кремлівська агресія проти України: роздуми в контексті війни: монографія. К.: НІСД, 2017. С. 33, 34. 
The policy of hybrid civilizational expansion was not chosen by the Kremlin regime of the Russian Federation by chance, because the bitter feeling of national resentment as a result of the defeat in the Cold War, the collapse of the USSR and the loss of superpower status has not yet disappeared in Russian society. Not risking engaging in an open military confrontation with NATO, Russia carries out hybrid attacks against the West in different directions, successfully using the vulnerabilities of Western democracies.

The Kremlin is not satisfied with the world order that emerged at the beginning of the XXIst century, which is why it seeks to destroy it, plunge into continuous chaos, trying to reformat the system of international relations on more favorable terms for its own globalist project. The first victims of hybrid aggression were the countries of the former Soviet Union, which are the closest neighbors of the Russian Federation, primarily Georgia and Ukraine. If the so-called war of 08.08 .08 was predominantly a "normal" military operation of the armed forces, then the hostile actions launched by the Kremlin against Ukraine had a more pronounced hybrid character. Their goal was to destroy (at least a significant decrease) the ability of the state system to defend itself by widely using the initiated protest moods of the population, introducing an "information virus" into the system of values of the mass consciousness, eliminating, bribing, discrediting the country's military and political leadership, etc. ${ }^{20}$.

One of the modern manifestations of the hybrid information war, which is actively used by the Russian Federation, is a "semantic" war, when the aggressor seeks to level all the national values and priorities of his opponent in the information field. To thus disarm him mentally, morally and psychologically.

\section{CONCLUSIONS}

In general, considering the concept of "hybrid war", we can conclude that this is a kind of war that combines a wide range of actions developed by the enemy using both military and irregular formations, in which civilian components also participate. In the

${ }^{20}$ Гібридна війна: in verbo et in praxi: монографія. Донецьькии національний університет імені Василя Стуса. Ред. Р.О. Додонов. Вінниця: ТОВ «НіланЛТД», 2017. C. 383. 
writings of military experts, the term "war of controlled chaos" is also close to this.

Modern wars and military-political conflicts have significant differences from previous models. The reasons that give rise to them lie not only in the economic, political or military-strategic spheres. They are also driven by the modern development of the information society.

In general, it should be noted that the essence of hybrid warfare is due to a number of factors and trends, among which there are aspects of an objective nature (changing economic, political realities of the country) and subjective reasons - primarily related to the hybrid nature of the war. Hybridity provides for a large role of information impacts on the population, is conducted at all levels of communication, affecting all aspects of the worldview. Also, one of the indicators of hybrid warfare is the use of asymmetric military operations, which are characterized by a significant difference in military force and the strategies and tactics of the participating countries. This is the meaning of hybrid aggression.

In general, it should be summarized that modern methods of conducting hybrid warfare provide, first of all, for the active and comprehensive use of means of information-psychological influence on the enemy. Cyber attacks are increasingly being used as a means of achieving the common goals of the aggressor.

The modern hybrid warfare is universal in nature, because - it is being fought at the information-political, financial, economic and legal levels - hybrids capture territories and infrastructure on the demarcation line, and the Ukrainian government, unfortunately, does not counteract this, motivating with democratic legislation. Therefore, first of all, it is important to change the legislation.

The strategic goal of the enemy's information activity remains large-scale destabilization of the state and the country as a whole, which usually manifests itself in the implementation of various kinds of subversive actions. This is one of the essential prerequisites for the effective implementation of the entire complex of measures of the hybrid information war. Given this, the official priorities of the state information policy are extremely important. Also effective means of counteracting the methods of hybrid information warfare is the active 
activity of the state in the external information arena and proper opposition to the activities of the special services of the aggressor.

\section{SUMMARY}

An attempt is made to consider the evolution of the hybrid information war in the context of the aggressive policy of the Kremlin regime of the Russian Federation. The attention is focused on the fact that the hybrid phenomenon-information warfare is a relatively new but it has some origins in history and finally formed in the twentieth century, it has every reason to develop in the twenty-first century. Emphasized that one of the most significant manifestations of the hybrid information war in the modern world is its application in the context of the current Russian aggression against Ukraine. This is especially true, because now the Ukrainian government, once again, in the early twentieth century faced with the manifestations of a system of aggression and expansion of the Kremlin regime. It is noted that the nature of hybrid war is caused by several factors, among which are aspects of objective and subjective reasons, primarily associated with the hybrid nature of the war. It is noted that hybridity involves a lot of role information impacts on the population, which are conducted on all levels of communication, affecting all sides of the world. At the same time one of the indicators of a hybrid war is the use of asymmetric fighting, which is characterized by a significant difference in military strength and strategy of the parties involved, what is the meaning of hybrid aggression. Stated that modern methods of waging a hybrid war provide the full and active use of means of information and psychological impact on the enemy and is increasingly used cyber attacks as a means of achieving the overall goals of the aggressor. Summarized that the modern hybrid warfare has a universal character because it is carried out on the information-political, financialeconomic and legal levels - hybrids captured territory and infrastructure on the boundary line, but the Ukrainian government, unfortunately, does not oppose this, citing the democratic legislation. And the strategic goal of information activities of the enemy remains the large-scale destabilisation of the state and the country as a whole, which is usually expressed in the implementation of different kind of Subversion. This is one of the essential prerequisites for effective carrying out of all complex events, hybrid and informational war. 
Given this, it is extremely important the official priorities of the state information policy. It is also an effective means of countering hybrid methods of information wars is the activity of the state in the external arena of information and appropriate counter-intelligence activities of the aggressor.

\section{REFERENCES}

1. Світова гібридна війна: український фронт: монографія. Ред. В. П. Горбулін. К.: НІСД, 2017. 496 с.

2. Що таке гібридна війна? Концепція і тактика гібридної війни. URL: http://faqukr.ru/novini-ta-suspilstvo/145715-shho-takegibridna-vijna-koncepcija-i-taktika.html

3. Гісем О. В. Всесвітня історія XX cm. Довідник. Кам'янецьПодільський: Абетка, 2003. 639 с.

4. Ситник О.М. Гібридний характер російсько-української війни 2014-2017 років та пошук ефективних засобів протидії. Війна на Донбасі. 2014-2016 рр.: зб. наук. пращь за матеріалами Другої Всеукраӥнської наукової військово-історичної конференціі «Війна на донбасі. 2014-2016 рр.» (м. Київ, 20 квітня 2017 р.). К.: Національний військово-історичний музей України, 2017. C. 135-142.

5. Яворська Г. М. Концепт «війна»: семантика і прагматика. Стратегічні пріоритети. Серія: Філософія. 2016. № 1. С. 14-23.

6. Турченко Ф. Турченко Г. Проект «Новоросія» $i$ новітня російсько-украӥнська війна. К.: Інститут історії України НАН України, 2015. 166 с.

7. Высказывания маршала Маннергейма, которые как бы обращены к Украине. URL: http://from-ua.com/news/405413viskazivaniya-marshala-mannergeima-kotorie-kak-bi-obrascheni-kukraine.html

8. Маннергейм К. Г. Э. Мемуары; Сайт «Военная литература». URL: http://militera.lib.ru/memo/other/mannerheim/ index.html

9.«РФ прагне створення «народної республіки» на Балканах»: президент Хорватії занепокоїлася активністю Росії у Босніi. URL: http://patrioty.org.ua/politic/rf-prahne-stvorennianarodnoi-respubliky-na-balkanakh-prezydent-khorvatii-zanepokoila sia-aktyvnistiu-rosii-u-bosnii-144812.html 
10. Стратегія і тактика гібридних війн в контексті військової агресії Росії проти України. Незалежний аналітичний центр геополітичних досліджень Борисфен Інтел. URL: http:// bintel.com.ua/uk/article/gibrid-war/

11. Світова гібридна війна: украӥнський фронт: монографія. Ред. В. П. Горбулін. К.: НІСД, 2017. 496 с.

12. Що таке гібридна війна? Концепція і тактика гібридної війни. URL: http://faqukr.ru/novini-ta-suspilstvo/145715-shho-takegibridna-vijna-koncepcija-i-taktika.html

13. Бадах Ю. Г. «Холодна війна». загальний огляд (19461991 рр.): [Електронний ресурс]. «Холодна війна»: історія та уроки. 1946-1991 рр.».: матеріали Міжнародної наукової військово-історичної конференції, 4-5 жовтня 2012 року, м. Севастополь. URL: http://nvimu.com.ua/wp-content/uploads/ Pages.pdf

14. Гібридна війна: in verbo et in praxi: монографія. Донецький національний університет імені Василя Стуса. Ред. Р.О. Додонов. Вінниця: ТОВ «НіланЛТД», 2017. 412 с.

15. Блоцкий O. Психология войны. URL: http://samlib.ru/b/ blockij_o_m/psihologijawojny.shtml

16. Власюк О.С. Кремлівська агресія проти Украӥни: роздуми в контексті війни: монографія. К.: НІСД, 2017. 304 с.

17. Психология войны. URL: http://samlib.ru/b/blockij_o_m/ psihologijawojny.shtml

\section{Information about the author: Sytnyk O. M.}

Doctor of Historical Sciences, Associate Professor, Head of the Department of History, Archeology and Philosophy, Bogdan Khmelnytskyi Melitopol State Pedagogical University 41/7, Universitetskaya str., Melitopol, 72312, Ukraine 
NOTES 
NOTES 
NOTES 
Publishing house "Liha-Pres"

9 Kastelivka str., Lviv, 79012, Ukraine 44 Lubicka str., Toruń, 87-100, Poland

Printed by the publishing house "Liha-Pres"

Passed for printing: September 17, 2019.

A run of 150 copies. 